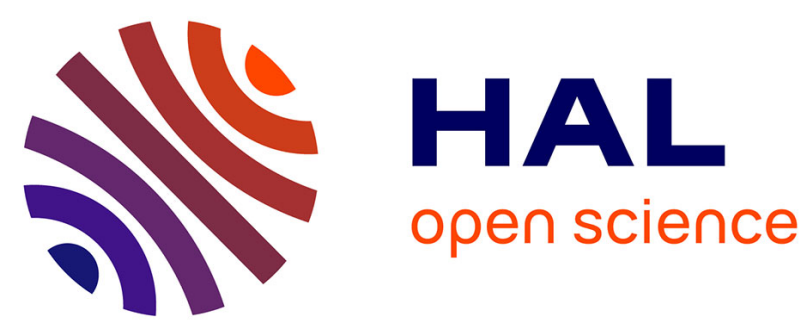

\title{
Thermal Decomposition of Fluoroalkyl Pentacarbonylmanganese(I) Derivatives by $\alpha$-Fluorine Elimination
}

\author{
Roberto Morales-Cerrada, Christophe Fliedel, Florence Gayet, Vincent \\ Ladmiral, Bruno Ameduri, Rinaldo Poli
}

\section{To cite this version:}

Roberto Morales-Cerrada, Christophe Fliedel, Florence Gayet, Vincent Ladmiral, Bruno Ameduri, et al.. Thermal Decomposition of Fluoroalkyl Pentacarbonylmanganese(I) Derivatives by $\alpha$-Fluorine Elimination. Organometallics, 2019, 38 (5), pp.1021-1030. 10.1021/acs.organomet.8b00721 . hal02064416

\section{HAL Id: hal-02064416 \\ https://hal.science/hal-02064416}

Submitted on 30 Oct 2020

HAL is a multi-disciplinary open access archive for the deposit and dissemination of scientific research documents, whether they are published or not. The documents may come from teaching and research institutions in France or abroad, or from public or private research centers.
L'archive ouverte pluridisciplinaire HAL, est destinée au dépôt et à la diffusion de documents scientifiques de niveau recherche, publiés ou non, émanant des établissements d'enseignement et de recherche français ou étrangers, des laboratoires publics ou privés. 


\title{
Thermal decomposition of fluoroalkyl pentacarbonylmanganese(l) derivatives by alpha-fluorine elimination.
}

\author{
Roberto Morales-Cerrada, ${ }^{\mathrm{a}, \mathrm{b}}$ Christophe Fliedel, ${ }^{\mathrm{a}}$ Florence Gayet, ${ }^{\mathrm{a}}$ Vincent Ladmiral, ${ }^{\mathrm{b}}$ Bruno \\ Améduri, ${ }^{b^{*}}$ Rinaldo Poli ${ }^{\mathrm{a}, \mathrm{c}^{*}}$ \\ ${ }^{a}$ LCC-CNRS (Laboratoire de Chimie de Coordination), Université de Toulouse, UPS, INPT, 205 route de Narbonne,

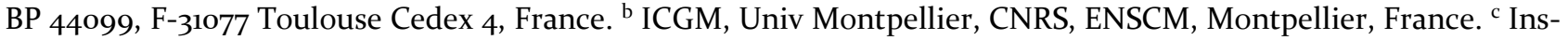 \\ titut Universitaire de France, 1, rue Descartes, 75231 Paris Cedex 05, France.
}

\begin{abstract}
This contribution brings to light the first example of an $\alpha$-F elimination process in manganese organometallic chemistry. As shown in a recent contribution (Chem. Eur. J., DOI: 10.1002/chem.201804007) the thermal decomposition of compounds $\left[\mathrm{Mn}\left(\mathrm{R}_{\mathrm{F}}\right)(\mathrm{CO})_{5}\right]\left(\mathrm{R}_{\mathrm{F}}=\mathrm{CF}_{3} ; \mathbf{1}, \mathrm{CHF}_{2}, \mathbf{2}, \mathrm{CH}_{2} \mathrm{CF}_{3}, 3\right)$ in $\mathrm{C}_{6} \mathrm{D}_{6}$ at 70-100 ${ }^{\circ} \mathrm{C}$ leads primarily to homolytic Mn- $\mathrm{R}_{\mathrm{F}}$ bond cleavage, followed by $\mathrm{R}_{\mathrm{F}}{ }^{\cdot}$ trapping in the presence of $\left(\mathrm{Me}_{3} \mathrm{Si}\right)_{3} \mathrm{SiH}$ (TTMSS), to yield $\mathrm{R}_{\mathrm{F}}-\mathrm{H}$. However, the formation of other products was revealed by a detailed ${ }^{19} \mathrm{~F}$ NMR investigation. Compounds $\mathbf{1}$ and $\mathbf{2}$ also produced significant amounts of $\left(\mathrm{Me}_{3} \mathrm{Si}\right)_{3} \mathrm{SiF}$ and of $\mathrm{F}$-poorer organic compounds (namely, $\mathrm{CH}_{2} \mathrm{~F}_{2}$ and $\mathrm{CH}_{3} \mathrm{~F}$ from $\mathbf{1} ; \mathrm{CH}_{3} \mathrm{~F}$ from $\mathbf{2}$ ). The extent of this additional process was rather important $(67 \%)$ for 1 but minor $(10 \%)$ for 2 . On the other hand, no traces of either $\left(\mathrm{Me}_{3} \mathrm{Si}\right)_{3} \mathrm{SiF}$ or $\mathrm{CH}_{3} \mathrm{CHF}_{2}$ were detected during the decomposition of 3. A DFT investigation shows that the process occurs via CO dissociation followed by $\alpha-F$ elimination from $\left[\mathrm{Mn}\left(\mathrm{R}_{\mathrm{F}}\right)(\mathrm{CO})_{4}\right]$ to yield $\left[\right.$ cis-MnF(CXF) $\left.(\mathrm{CO})_{4}\right](\mathrm{X}=\mathrm{F}$ for $\mathbf{1}, \mathrm{H}$ for $\mathbf{2})$. The latter can then react with TTMSS via a rate-determining transition state, which is located at a comparable energy to that of the homolytic bond breaking asymptote, to yield $\left(\mathrm{Me}_{3} \mathrm{Si}\right)_{3} \mathrm{SiF}$ and $\left[\mathrm{Mn}(\mathrm{CXHF})(\mathrm{CO})_{5}\right]$ after $\mathrm{CO}$ addition. The greater extent of $\left(\mathrm{Me}_{3} \mathrm{Si}\right)_{3} \mathrm{SiF}$ formation produced by the $\mathrm{H} / \mathrm{F}$ exchange in the order $\mathbf{1}>\mathbf{2}$ agrees with the stronger Mn- $\mathrm{R}_{\mathrm{F}}$ bond in the same order. Analysis of the relative barriers for the two competitive processes at $100{ }^{\circ} \mathrm{C}$ confirms that the experimentally determined $\Delta H^{\ddagger}$ for the thermal decompositions of $\mathbf{1}, \mathbf{2}$ and $\mathbf{3}$ are close estimates of the $\mathrm{Mn}-\mathrm{R}_{\mathrm{F}}$ bond dissociation energies (BDEs).
\end{abstract}

\section{Introduction}

Recently, the homolytic Mn- $\mathrm{R}_{\mathrm{F}}$ bond strength in pentacarbonylmanganese(I) derivatives with fluorinated alkyl groups, $\left[\mathrm{Mn}\left(\mathrm{R}_{\mathrm{F}}\right)(\mathrm{CO})_{5}\right]\left(\mathrm{R}_{\mathrm{F}}=\mathrm{CF}_{3}, \mathbf{1} ; \mathrm{CHF}_{2}, \mathbf{2}, \mathrm{CH}_{2} \mathrm{CF}_{3}, 3\right)$ has been investigated in our laboratory, ${ }^{1}$ because of our interest in the generation of fluoroalkyl radicals, $\mathrm{R}_{\mathrm{F}}{ }^{\circ}$, and their use in radical polymerization of fluorinated monomers, ${ }^{2,3}$ notably vinylidene fluoride (VDF). 4, 5 The investigation was carried out by the kinetic approach, thermally promoting the bond cleavage in the presence of an efficient trapping agent and assuming that the kinetic activation parameters $\left(\Delta \mathrm{H}_{\mathrm{a}}^{\ddagger}, \Delta \mathrm{S}_{\mathrm{a}}^{\ddagger}\right)$ represent good estimates of the thermodynamic bond strength parameters $\left(\Delta \mathrm{H}^{\circ}, \Delta \mathrm{S}^{\circ}\right)$. This is justified by the expected low recombination barrier for the encounter of the $\left[\mathrm{Mn}(\mathrm{CO})_{5}\right]^{\circ}$ and $\mathrm{R}_{\mathrm{F}}{ }^{*}$ radicals. Tris(trimethylsilyl)silane (TTMSS) was used for this purpose (see Scheme 1).

The proposed fate of the $\left[\mathrm{Mn}(\mathrm{CO})_{5}\right]^{\cdot}$ and $\left(\mathrm{Me}_{3} \mathrm{Si}\right)_{3} \mathrm{Si}$ radicals (equations 3-5), comes from the literature reports on the efficient dimerization of both $\left[\mathrm{Mn}(\mathrm{CO})_{5}\right]^{\cdot 6}$ and $\left(\mathrm{Me}_{3} \mathrm{Si}_{3}\right)_{3} \mathrm{Si}^{7}$, and from the report of the high-yield preparation of $\left[\mathrm{Mn}\left\{\mathrm{Si}\left(\mathrm{SiMe}_{3}\right)_{3}\right\}(\mathrm{CO})_{5}\right]^{8-10}$ by the reaction between $\left[\mathrm{Mn}_{2}(\mathrm{CO})_{10}\right]$ and TTMSS in a sealed tube. ${ }^{8}$ Given the high strength of these $\mathrm{Mn}-\mathrm{R}_{\mathrm{F}}$ bonds, the investigation required quite high temperatures $\left(70-100{ }^{\circ} \mathrm{C}\right)$ but provided the desired information, which is summarized in Table 1 . The obtained parameters agree rather well with two different computational estimates, ${ }^{11}, 12$ but the $\Delta \mathrm{H}$ values are significantly higher than previous experimental estimates (limited to compounds 1 and 2) based on indirect calorimetric and gas-phase mass spectrometry measurements. ${ }^{13,14}$

Scheme 1. Thermal decomposition of (fluoro)alkylpentacarbonylmanganese(I) compounds in the presence of TTMSS as a radical trap.

$$
\begin{aligned}
& {\left[(\mathrm{CO})_{5} \mathrm{Mn}-\mathrm{R}_{\mathrm{F}}\right] \stackrel{k_{\mathrm{a}}}{k_{\mathrm{da}}}\left[(\mathrm{CO})_{5} \mathrm{Mnn}\right]^{\cdot}+\mathrm{R}_{\mathrm{F}}^{\cdot}} \\
& \left(\mathrm{SiMe}_{3}\right)_{3} \mathrm{Si}-\mathrm{H}+\mathrm{R}_{\mathrm{F}} \cdot \stackrel{k_{\mathrm{trap}}}{\longrightarrow}\left(\mathrm{SiMe}_{3}\right)_{3} \mathrm{Si}+\mathrm{R}_{\mathrm{F}}-\mathrm{H} \\
& 2\left[(\mathrm{CO})_{5} \mathrm{Mn}\right]^{\cdot} \stackrel{k_{\mathrm{dim}, \mathrm{Mn}}}{\longrightarrow}\left[\mathrm{Mn}_{2}(\mathrm{CO})_{10}\right] \\
& 2\left(\mathrm{SiMe}_{3}\right)_{3} \mathrm{Si} \stackrel{k_{\mathrm{dim}, \mathrm{Si}}}{\longrightarrow} \mathrm{Si}_{2}\left(\mathrm{SiMe}_{3}\right)_{6} \\
& {\left[\mathrm{Mn}_{2}(\mathrm{CO})_{10}\right]+\left(\mathrm{SiMe}_{3}\right)_{3} \mathrm{Si}-\mathrm{H} \stackrel{k_{\text {trap, }, \mathrm{Mn}}}{\longrightarrow}\left[(\mathrm{CO})_{5} \mathrm{Mn}-\mathrm{Si}\left(\mathrm{SiMe}_{3}\right)_{3}\right]+\mathrm{H}_{2}}
\end{aligned}
$$

The ${ }^{19} \mathrm{~F}$ NMR monitoring of the $\left[\mathrm{Mn}\left(\mathrm{R}_{\mathrm{F}}\right)(\mathrm{CO})_{5}\right]$ decay in $\mathrm{C}_{6} \mathrm{D}_{6}$ also revealed, qualitatively, the production of the expected $\mathrm{R}_{\mathrm{F}}-\mathrm{H}$ product. Quantitative information could not be obtained because these products are gases (b.p. $=-82.1{ }^{\circ} \mathrm{C}$ for $\mathrm{CF}_{3} \mathrm{H},-51.7{ }^{\circ} \mathrm{C}$ for $\mathrm{CH}_{2} \mathrm{~F}_{2}$ and $-47.6{ }^{\circ} \mathrm{C}$ for $\mathrm{CH}_{3} \mathrm{CF}_{3}$ ) with little solubility in the NMR solvent. Hence, they extensively escaped toward the NMR tube headspace. However, a more careful inspection of the NMR spectra also revealed the formation of other products, indicating that the reactions de- 
picted in Scheme 1 represent only one pathway of the compound decomposition. We were therefore interested in learning about the nature of these side products, the mechanism(s) by which they are formed, and how much these additional pathways have an impact on the values reported in Table 1 . More specifically, what is the reliability of the determined $\Delta H^{\ddagger}$ as an approximation of the Mn- $\mathrm{R}_{\mathrm{F}} \mathrm{BDE}$ ? The results of these investigations, which most notably involve an unprecedented $\alpha-F$ elimination process for a manganese system, ${ }^{15}$ are reported in the present contribution.

Table 1. Activation parameters for the homolytic Mn$R_{F}$ bond cleavage in compounds $\left[\mathrm{Mn}\left(R_{\mathrm{F}}\right)(\mathrm{CO})_{5}\right]\left(\mathbf{R}_{\mathrm{F}}=\right.$ $\left.\mathrm{CF}_{3}, 1 ; \mathrm{CHF}_{2}, 2 ; \mathrm{CH}_{2} \mathrm{CF}_{3}, 3\right)$ and comparison with the computed bond strengths.

\begin{tabular}{lllllll}
\hline & \multirow{4}{*}{$\mathrm{R}_{\mathrm{F}}$} & \multicolumn{2}{c}{$\Delta H^{\ddagger} / \mathrm{kcal} \mathrm{mol}^{-1}$} & \multicolumn{3}{c}{$\Delta S^{\ddagger} / \mathrm{cal} \mathrm{mol}^{-1} \mathrm{~K}^{-1}$} \\
& & Exp. $^{\mathrm{a}}$ & $\mathrm{DFT}^{\mathrm{b}}$ & $\mathrm{DFT}^{\mathrm{c}}$ & Exp. & $\mathrm{DFT}^{\mathrm{b}}$ \\
\hline 1 & $\mathrm{CF}_{3}$ & $53.8 \pm 3.5$ & 55.1 & 53.6 & $66.0 \pm 9.5$ & 39.6 \\
2 & $\mathrm{CHF}_{2}$ & $46.3 \pm 1.6$ & 48.0 & 48.5 & $55.8 \pm 4.7$ & 37.1 \\
3 & $\mathrm{CH}_{2} \mathrm{CF}_{3}$ & $50.6 \pm 0.8$ & 50.5 & - & $65.4 \pm 2.2$ & 42.5 \\
\hline
\end{tabular}

a Values from ref. ${ }^{1}{ }^{\mathrm{b}}$ Values from ref. ${ }^{11} .{ }^{\mathrm{c}}$ Values from ref. ${ }^{12}$.

\section{Results and Discussion}

\section{(a) Experimental investigations}

The main products of the $\left[\mathrm{Mn}\left(\mathrm{R}_{\mathrm{F}}\right)(\mathrm{CO})_{5}\right]$ decomposition in the presence of TTMSS, $\mathrm{R}_{\mathrm{F}}-\mathrm{H}$ (Scheme 1 , equation $2 ; \mathrm{R}_{\mathrm{F}}=\mathrm{CF}_{3}$, $\mathrm{CHF}_{2}, \mathrm{CH}_{2} \mathrm{CF}_{3}$ ) were identified by weak signals, because of their volatility and poor solubility in the NMR solvent. Compound $\mathrm{CF}_{3} \mathrm{H}$ could only be observed by ${ }^{1} \mathrm{H}-{ }^{19} \mathrm{~F}$ HETEROCOSY NMR at $10{ }^{\circ} \mathrm{C}$ as a quartet at $\delta 5.59\left({ }^{1} \mathrm{H}\right)$ coupled with a doublet at $\delta-78.03\left({ }^{19} \mathrm{~F}\right)$ with a coupling constant ${ }^{2} J_{\mathrm{FH}}$ of $78 \mathrm{~Hz}$ (see Figure S.A1), which is in good agreement with the ${ }^{1} \mathrm{H}$ and ${ }^{19} \mathrm{~F}$ NMR resonances reported in the literature at $\delta 6.25\left({ }^{2} \mathrm{~J} \mathrm{HF}\right.$ $=79.2 \mathrm{~Hz})$ in cyclohexane ${ }^{16}$ and $-78.6\left({ }^{2} J_{\mathrm{FH}}=79 \mathrm{~Hz}\right),{ }^{17}$ respectively. The $\mathrm{R}_{\mathrm{F}}-\mathrm{H}$ products from the decomposition of $2\left(\mathrm{R}_{\mathrm{F}}=\right.$ $\left.\mathrm{CHF}_{2}\right)$ and $3\left(\mathrm{R}_{\mathrm{F}}=\mathrm{CH}_{2} \mathrm{CF}_{3}\right)$ could be directly observed in the ${ }^{19} \mathrm{~F}$ NMR spectrum: triplet at $\delta-142.4\left({ }^{2} \mathrm{~J}_{\mathrm{FH}}=49.8 \mathrm{~Hz}\right)$ for $\mathrm{CH}_{2} \mathrm{~F}_{2}\left(c f . \delta-143.6,{ }^{2} J_{\mathrm{FH}}=50.1 \mathrm{~Hz}\right),{ }^{17}$ see Figure $\mathrm{S} . \mathrm{A} 2$, and quartet at $\delta-60.7\left({ }^{3} J_{\mathrm{FH}}=12.6 \mathrm{~Hz}\right)$ for $\mathrm{CH}_{3} \mathrm{CF}_{3}\left(c f . \delta-61.7,{ }^{3} J_{\mathrm{FH}}=12.8\right.$ $\mathrm{Hz}){ }^{18}$ see Figure S.A3. However, the ${ }^{19} \mathrm{~F}$ NMR spectra also revealed additional resonances.

For the decomposition of $\mathbf{1}$, a key ${ }^{19} \mathrm{~F}$ NMR resonance is a strong singlet at $\delta$-256.2, characterized by ${ }^{29} \mathrm{Si}$ satellites (doublet, ${ }^{1} J_{\mathrm{SiF}}=327 \mathrm{~Hz}$ ), see Figure 1 , which is assigned to compound $\left(\mathrm{Me}_{3} \mathrm{Si}\right)_{3} \mathrm{SiF}$ (the full ${ }^{19} \mathrm{~F}$ NMR spectrum is shown in Figure S.A4). The shape of this resonance remains unchanged in the ${ }^{19} \mathrm{~F}\left\{{ }^{1} \mathrm{H},{ }^{13} \mathrm{C}\right\}$ NMR spectrum. The coupling constant is typical for a direct F-Si bond and the spectral parameters are in close agreement with those reported in the literature for this compound $\left(\delta-261,{ }^{1} J_{\mathrm{SiF}}=335 \mathrm{~Hz}^{19}\right.$ or $327.8 \mathrm{~Hz}$ from the ${ }^{29} \mathrm{Si}$ NMR study ${ }^{20}$ ). The ${ }^{1} \mathrm{H}-{ }^{19} \mathrm{~F}$ HETEROCOSY NMR spectrum shows that this resonance is coupled to a ${ }^{1} \mathrm{H}$ NMR resonance at $\delta$ o.21 (see Figure 1), which is also in agreement with the literature value $\left(\delta=0.21\right.$ in $\left.\mathrm{C}_{6} \mathrm{H}_{6}\right) .{ }^{19}$ As the only source of $\mathrm{F}$ in the experiment is the alkyl group of compound 1, this observation constitutes clear evidence for C-F bond breaking. Integration of this resonance relative to the $\mathrm{C}_{6} \mathrm{~F}_{6}$ internal standard (used for the kinetics investigation) shows that $67 \%$ of compound $\mathbf{1}$ has undergone the side reaction leading to $\left(\mathrm{Me}_{3} \mathrm{Si}\right)_{3} \mathrm{SiF}$.

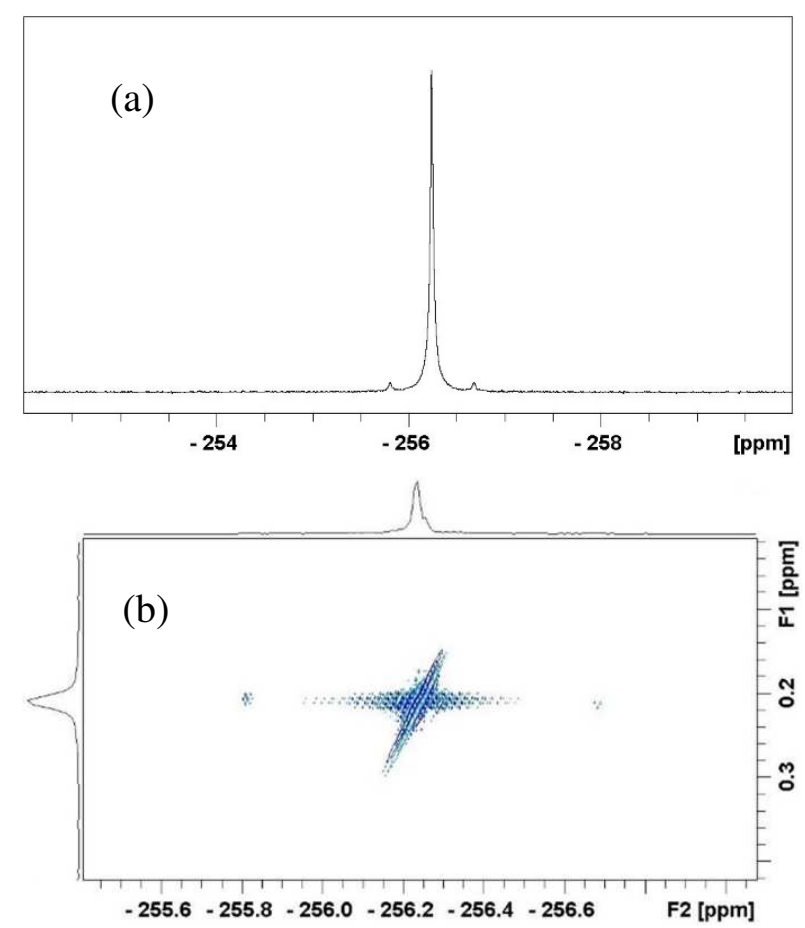

Figure 1. NMR spectra in $\mathrm{C}_{6} \mathrm{D}_{6}$ recorded at $10{ }^{\circ} \mathrm{C}$ after the decomposition of compound 1 at $100{ }^{\circ} \mathrm{C}$ for 1 hour in the presence of 10 equivalents of TTMSS, proving the presence of $\left(\mathrm{Me}_{3} \mathrm{Si}\right)_{3} \mathrm{SiF}$ : (a) expansion of the -252 to $-260 \mathrm{ppm}$ region of the ${ }^{19} \mathrm{~F}$ NMR spectrum (376.5 MHz, benzene- $\mathrm{d}_{6}$ ); (b) Expansion of the corresponding ${ }^{1} \mathrm{H}^{-19} \mathrm{~F}$ HETEROCOSY NMR resonance.

Confirmation of this occurrence comes from the identification of a small triplet resonance at the expected position for $\mathrm{CH}_{2} \mathrm{~F}_{2}\left(\delta-142.15,{ }^{2} J_{\mathrm{FH}}=50 \mathrm{~Hz}\right.$, see Figure $2 ; c f . \delta-142.0,{ }^{2} J_{\mathrm{FH}}$ $=50.3 \mathrm{~Hz}$ reported in the literature $\left.{ }^{21}\right)$. This signal correlates with a ${ }^{1} \mathrm{H}$ resonance at $\delta \quad 4.95$ in the ${ }^{1} \mathrm{H}-{ }^{19} \mathrm{~F}$ NMR HETEROCOSY spectrum $\left(c f . \delta 5.45,{ }^{2} J_{\mathrm{HF}}=50.22 \mathrm{~Hz}\right.$ in cyclohexan $\left.\mathrm{e}^{16}\right)$. The fact that this resonance is much smaller than that of $\left(\mathrm{Me}_{3} \mathrm{Si}\right)_{3} \mathrm{SiF}$ results from the volatility and small solubility of gaseous $\mathrm{CH}_{2} \mathrm{~F}_{2}$. The spectrum shows evidence for even deeper defluorination of the alkyl group, since an even smaller resonance is detected at the position expected for $\mathrm{CH}_{3} \mathrm{~F}(\delta$-270.34). The quartet feature is not well resolved, but the relationship with a ${ }^{1} \mathrm{H}$ doublet resonance $\left({ }^{2} J_{\mathrm{HF}} \mathrm{ca} .46 \mathrm{~Hz}\right)$ at $\delta$ ca. 5.7 is clearly indicated by the ${ }^{1} \mathrm{H}-{ }^{19} \mathrm{~F}$ HETEROCOSY NMR spectrum (see Figure 3 ). These values match rather well those available in the literature in the gas phase $\left(\delta_{\mathrm{F}}-270.6, \delta_{\mathrm{H}}\right.$ $\left.4.18,{ }^{2} J_{\mathrm{FH}}=46 \mathrm{~Hz}\right){ }^{22}$ Further discussion of this spectrum is available in the SI.

For the decomposition of 2 at $100{ }^{\circ} \mathrm{C}$, in addition to the resonance of the $\mathrm{CH}_{2} \mathrm{~F}_{2}$ product of $\mathrm{Mn}-\mathrm{R}_{\mathrm{F}}$ homolytic cleavage and trapping by TTMSS, the resonance of $\left(\mathrm{Me}_{3} \mathrm{Si}\right)_{3} \mathrm{SiF}$ at $\delta$ 255.12 was again observed (see full spectrum in Figure S.A6), indicating the occurrence of $\mathrm{C}-\mathrm{F}$ activation for the $\mathrm{CHF}_{2}$ group. However, the signal of the other expected product, 
$\mathrm{CH}_{3} \mathrm{~F}$, could not be detected in this case. Integration of the $\left(\mathrm{Me}_{3} \mathrm{Si}\right)_{3} \mathrm{SiF}$ resonance against the $\mathrm{C}_{6} \mathrm{~F}_{6}$ internal standard gave only $10 \%$ of side reaction for compound 2 .

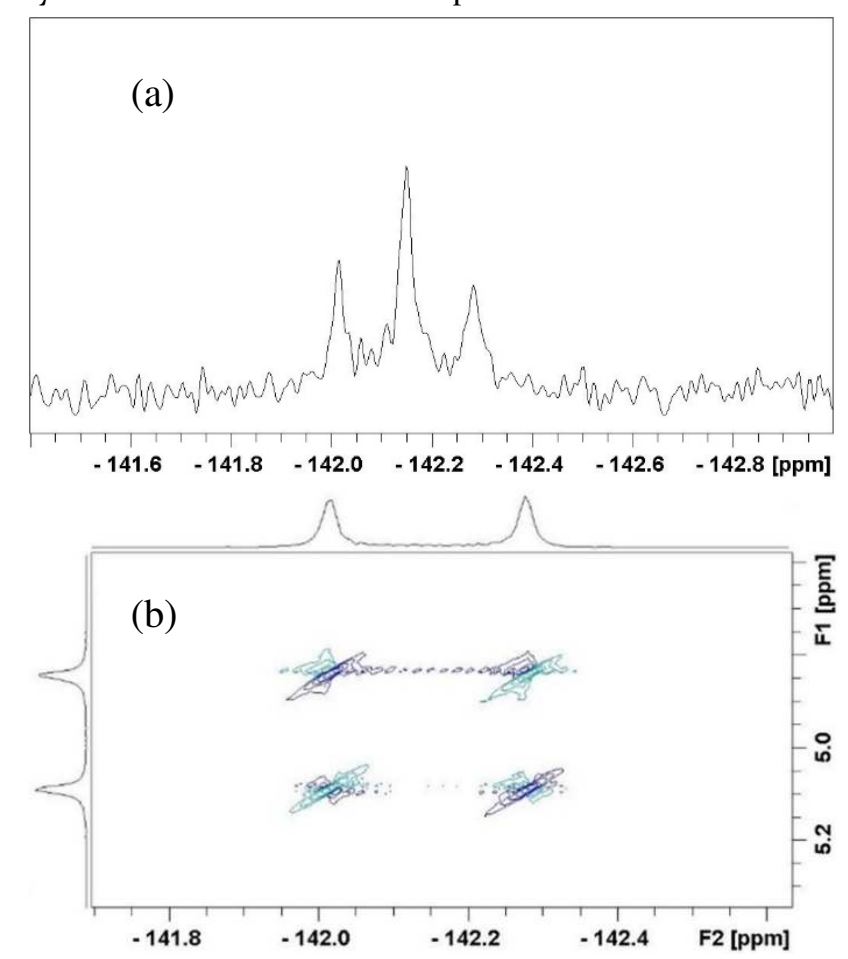

Figure 2. NMR spectra in $\mathrm{C}_{6} \mathrm{D}_{6}$ recorded at $10^{\circ} \mathrm{C}$ after the decomposition of compound $\mathbf{1}$ at $100{ }^{\circ} \mathrm{C}$ for 1 hour in the presence of 10 equivalents of TTMSS, proving the presence of $\mathrm{CH}_{2} \mathrm{~F}_{2}$ : (a) expansion of the -141.4 to $-143.0 \mathrm{ppm}$ region of the ${ }^{19} \mathrm{~F}$ NMR spectrum (376.5 MHz); (b) Expansion of the corresponding ${ }^{1} \mathrm{H}-{ }^{19} \mathrm{~F}$ HETEROCOSY NMR resonance. Note that both ${ }^{1} \mathrm{H}$ and ${ }^{19} \mathrm{~F}{ }_{1} \mathrm{D}$ signals appear as doublets rather than triplets because the central resonance is silent by the antiphase cancellation.

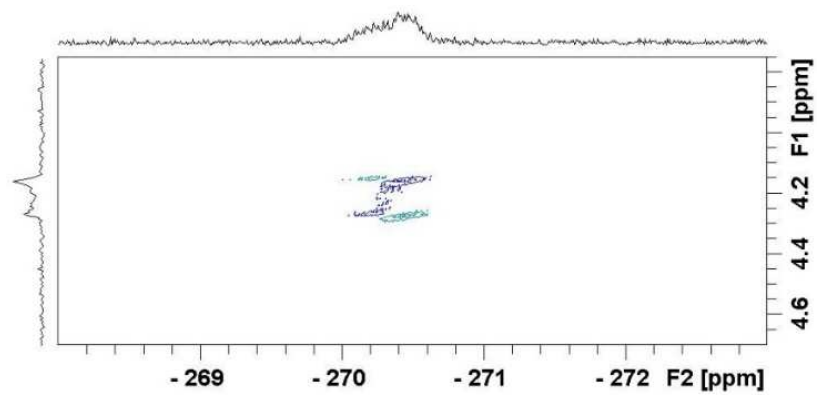

Figure 3. Detail of the ${ }^{1} \mathrm{H}-{ }^{19} \mathrm{~F}$ HETEROCOSY NMR spectrum in $\mathrm{C}_{6} \mathrm{D}_{6}$ recorded at $10{ }^{\circ} \mathrm{C}$ after the decomposition of compound 1 by heating at $100{ }^{\circ} \mathrm{C}$ for 1 hour in the presence of 10 equivalents of TTMSS, proving the presence of $\mathrm{CH}_{3} \mathrm{~F}$.

Finally, the degradation of 3 was not accompanied by the observation of either $\left(\mathrm{Me}_{3} \mathrm{Si}\right)_{3} \mathrm{SiF}$ or the putative products of $\mathrm{H} / \mathrm{F}$ exchange, namely $\mathrm{CH}_{3} \mathrm{CHF}_{2}$ or $\mathrm{CH}_{3} \mathrm{CH}_{2} \mathrm{~F}$, for which the resonances are expected at $\delta-25.9$ and +77.0 , respectively. ${ }^{23}$ Only a few very minor unidentified resonances in the ${ }^{19} \mathrm{~F}$ NMR spectrum, in addition to that of the expected $\mathrm{CH}_{3} \mathrm{CF}_{3}$ product at $\delta-60.86$, could be observed as noted in the full spectrum (Figure $\mathrm{S}_{\mathrm{A}} \mathrm{A}$ ). This result suggests that the reaction pathway leading to the formation of $\left(\mathrm{Me}_{3} \mathrm{Si}\right)_{3} \mathrm{SiF}$ by $\mathrm{H} / \mathrm{F}$ exchange with the $\mathrm{R}_{\mathrm{F}}$ group, which is the major secondary decomposition pathway in addition to the homolytic Mn- $\mathrm{R}_{\mathrm{F}}$ bond cleavage, is specific for groups that contain the $\mathrm{F}$ atom on the $\alpha-C$ atom and does not occur for $\beta-C-F$ bonds.

(b) DFT investigation of the homolytic cleavage and the side reaction pathway for compound 1

The calculations were carried at the same level of theory as in our previous study of the $\mathrm{Mn}-\mathrm{R}_{\mathrm{F}}$ bond strengths in compounds 1-3 (see details in the Experimental Section). ${ }^{11}$ The main target of these investigations was the rationalization of the observed $\mathrm{H} / \mathrm{F}$ exchange process for compounds 1 and 2 but not for compound 3 and to elucidate its mechanism. In addition, we also wished to assess the relative importance of the homolytic bond cleavage vs. the alternative pathway(s), in order to assess the quality of the previously determined activation parameters (Table 1$)^{1}$ as legitimate approximations of the thermodynamic bond dissociation parameters.

The two key experimental observations are that the H/F exchange occurs solely when the compound bears $\mathrm{F}$ atoms on the alkyl $\alpha-C$ atom and that the impact of this secondary reaction decreases in the order $\mathbf{1}>\mathbf{2}$. The likely source of the $\mathrm{H}$ atom is the silane reagent, since the exchange leads to the formation of the $\left(\mathrm{Me}_{3} \mathrm{Si}\right)_{3} \mathrm{SiF}$ co-product containing a very stable Si-F bond. The full mechanistic exploration was carried out only for compound 1. TTMSS was modeled by $\mathrm{SiH}_{4}$ for the purpose of computational efficiency.

\section{Scheme 2. Possible $\mathrm{H} / \mathrm{F}$ exchange and $\mathrm{CHF}_{3}$ generation from an acyl intermediate in compound 1.}

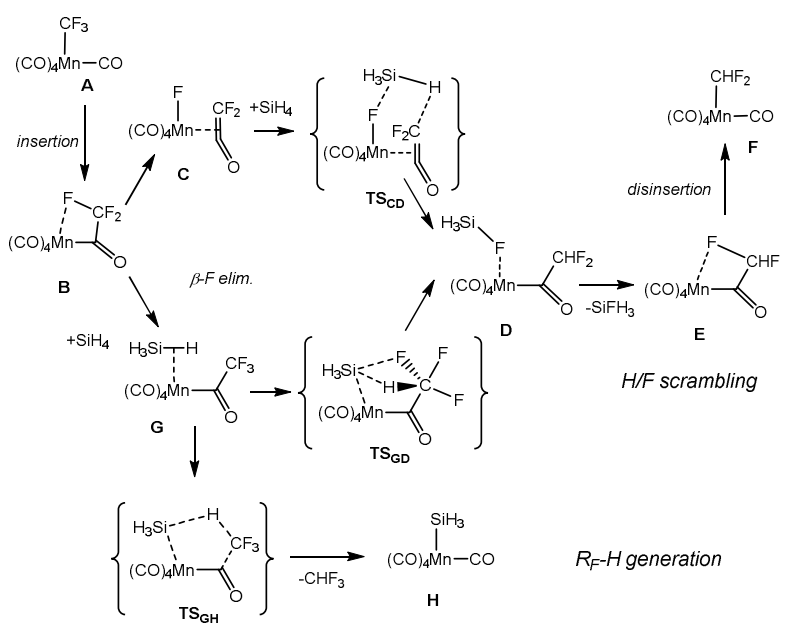

Since recent literature reports have shown the possibility of $\beta$-F elimination processes as key steps in catalyzed hydrodefluorination and in C-B, C-C and C-Si bond formation processes involving fluorinated olefins, ${ }^{15},{ }^{24-28}$ a first mechanistic hypothesis consisted of an $R_{F}$ migratory insertion, which would transfer the $F$ atom from the $\alpha$ to the $\beta$ position (Scheme 2). Alkyl pentacarbonylmanganese(I) compounds are well-known to undergo this process rather easily. ${ }^{29}$, 30 From the starting compound $\mathbf{A}$ (compound $\mathbf{1}$ ), migratory insertion of the $\mathrm{CF}_{3}$ group leads to a 16-electron $\left[\mathrm{Mn}\left(\mathrm{COR}_{\mathrm{F}}\right)(\mathrm{CO})_{4}\right]$ intermediate $\mathbf{B}$, which may be able to undergo a $\beta$-F elimination (Scheme 2, upper path) yielding the difluoroketene complex $\mathbf{C}$. The action of the silane may then 
lead to a difluoroacyl complex $\mathbf{D}$ where one coordination site is taken by the fluorosilane co-product. Final decoordination of the fluorosilane and disinsertion from the 16-electron acyl derivative $\mathbf{E}$ would generate $\mathbf{F}$ (complex 2), from which the observed $\mathrm{CH}_{2} \mathrm{~F}_{2}$ side product would eventually be generated by the homolytic cleavage and silane-trapping sequence of Scheme 1.

The DFT calculations indicate that the migratory insertion product, intermediate $\mathbf{B}$, is indeed accessible, via transition state $\mathbf{T S}_{\mathbf{A B}}$, since the latter has a lower Gibbs energy than the homolytic bond cleavage process, see Figure 4 . Not unexpectedly, the open coordination site in this unsaturated compound is stabilized by donation from a lone pair of one of the fluorine atoms of the trifluoroacetyl group. However, the proposed intermediate $\mathbf{C}$ is shown by the calculations to lie at very high energy, $56.2 \mathrm{kcal} / \mathrm{mol}$ above A. The transition state $\mathbf{T S}_{\mathrm{BC}}$ would obviously be at even higher energy. Therefore, this pathway is not kinetically competent for the observed $\mathrm{H} / \mathrm{F}$ exchange. An alternative way to transform $\mathbf{B}$ into D would consist of silane addition to $\mathbf{B}$ to generate adduct $\mathbf{G}$, which could then accomplish the $\mathrm{H} / \mathrm{F}$ exchange associatively via hypervalent $\mathrm{C}$ and $\mathrm{Si}$ atoms (Scheme 2, lower path). The optimization of the silane adduct $\mathbf{G}$ has indeed provided a stable local minimum, shown in Figure 4. This is an electronically saturated $\sigma$-complex, where the silane $\mathrm{Si}-\mathrm{H}$ bond provides two electrons to the metal center. The interaction is very weak, since the Gibbs energy is barely lower than for the sum of the two isolated species. However, all attempts to locate system $\mathbf{T S}_{\mathbf{G D}}$ or a related stationary point along the path from $\mathbf{G}$ to $\mathbf{D}$ failed, leading instead to a rearrangement to an oxacyclopropyl compound $\mathbf{J}$ via an intermediate $\mathbf{I}$ and a relaxed scan along the $\mathrm{Si} \cdots \mathrm{F}$ distance indicated that this transition state must be located at $>45 \mathrm{kcal} / \mathrm{mol}$ higher than $(\mathbf{A}+$ $\mathrm{SiH}_{4}$ ). Details of these attempts and on the resulting products are available in the SI, section B1. In addition, intermediate $\mathbf{G}$ may also be envisaged to yield the observed $\mathrm{CHF}_{3}$ product directly, with concomitant formation of the manganese silyl derivative $\mathbf{H}$ (Scheme 2 ). While this possibility would not account for the $\mathrm{H} / \mathrm{F}$ exchange process, it would constitute a possible lower energy pathway, relative to the homolytic Mn$\mathrm{C}$ bond cleavage, for the production of the main $\mathrm{R}_{\mathrm{F}}-\mathrm{H}$ decomposition product. However, attempts to locate $\mathbf{T S}_{\mathbf{G H}}$ also failed and a relaxed scan along the $\mathrm{C} \cdot \mathrm{.H}$ distance indicated that this transition state must be located at $>60 \mathrm{kcal} / \mathrm{mol}$ higher than $\left(\mathbf{A}+\mathrm{SiH}_{4}\right)$, see details in the SI, Figure S.B2. In conclusion, no viable pathway could be found for either the $\mathrm{H} / \mathrm{F}$ scrambling process or for the $\mathrm{CHF}_{3}$ product formation via the acyl product of migratory insertion.

An alternative process, known to occur for pentacarbonylmanganese(I) derivatives under thermal solicitation, is carbon monoxide dissociation, transforming $\mathbf{A}$ to the tetracarbonyl derivative $\mathbf{K}$ (Scheme 3). From this intermediate, a conceivable pathway leading to the $\mathrm{H} / \mathrm{F}$ scrambling would involve $\alpha-F$ elimination to yield a fluoro(difluoroalkylidene) derivative $\mathbf{L}$, which would react with the silane to yield the

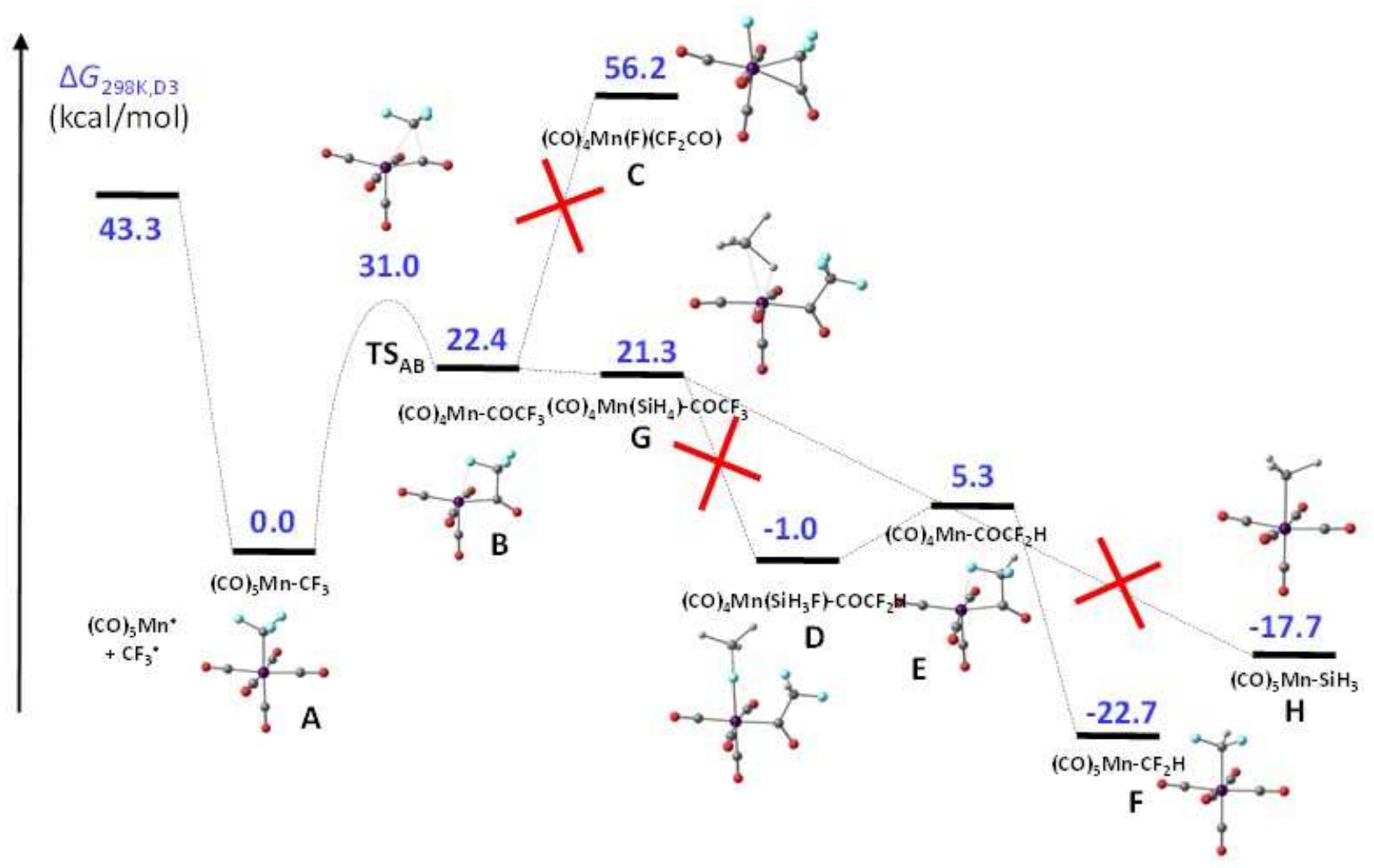

Figure 4. Energy profiles (relative $\mathrm{D}_{3}$-corrected $\mathrm{G}_{298}$ values in $\mathrm{kcal} / \mathrm{mol}$ ) and views of the optimized geometries for the pathways illustrated in Scheme 2. 
difluoromethyl derivative $\mathbf{M}$ with a coordinated $\mathrm{SiFH}_{3}$. The latter would finally be replaced by carbon monoxide and yield $\mathbf{F}$, source of the observed $\mathrm{CH}_{2} \mathrm{~F}_{2}$ by-product by the homolytic bond cleavage pathway. Like $\beta-F$ elimination, $\alpha-F$ elimination was shown to be involved in a variety of stoichiometric and catalytic reactions, ${ }^{15}, 3^{1-38}$ although to the best of our knowledge this phenomenon is unprecedented in manganese chemistry.

Scheme 3. Possible $\mathrm{H} / \mathrm{F}$ exchange and $\mathrm{CHF}_{3}$ generation following the decarbonylation of compound 1.

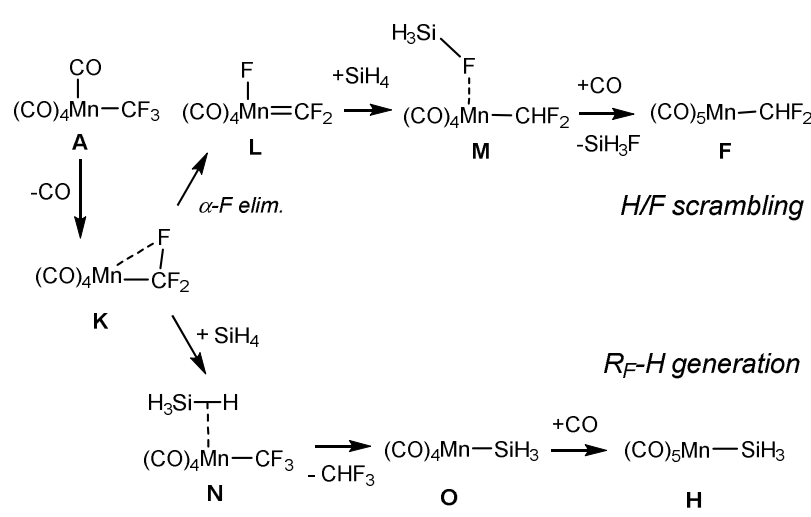

The energy profile for this pathway is displayed in Figure 5, again in comparison with the homolytic bond cleavage process, which is shown on the left-hand side. The decarbonylation is predicted by the calculations to be thermody- namically accessible. The coordinatively unsaturated tetracarbonyl derivative $\mathbf{K}$ is stabilized by the lone pair of one of the $\alpha-F$ atoms, resulting in a significant distortion of the $C$ atom geometry (Mn-C-F angle of $78.2^{\circ}$ and C-F bond lengthened to $1.460 \AA$, vs. distances of $1.339 \AA$ for the other two C-F bonds). The $\alpha$-F elimination process is also thermally accessible, the transition state $\left(\mathbf{T S}_{\mathrm{KL}}\right)$ being located at a slightly lower energy than that of the homolytic bond cleavage products. The interaction with $\mathrm{SiH}_{4}$ leading to $\mathrm{H} / \mathrm{F}$ scrambling is also accessible, with an energy cost very close to that of the bond cleavage, with a transition state $\left(\mathrm{TS}_{\mathrm{LM}}\right)$ located only 0.4 $\mathrm{kcal} / \mathrm{mol}$ higher than the bond cleavage products. Relaxation of this TS leads to a van der Waals adduct of $\mathbf{L}$ with $\mathrm{SiH}_{4}$ on the reactant side and to $\mathbf{M}$ on the product side. The relative energy of $\mathbf{T S}_{\mathrm{LM}}$ seems consistent with the fact that this is an observed competitive reaction in addition to the homolytic bond cleavage.

The intermediate $\mathbf{K}$ also opens access to another possible pathway for release of the observed $\mathrm{CHF}_{3}$ product, as shown in Scheme 3. Coordination of the silane yields the $\sigma$-complex $\mathbf{N}$, where the silane $\mathrm{H}$ atom transfer to the $\mathrm{C}$ atom produces the coordinatively unsaturated silyl complex $\mathbf{O}$, which is then saturated by $\mathrm{CO}$ coordination to generate $\mathbf{H}$. The DFTcalculated energy profile shows the feasibility of this process, see Figure 6. Coordination of the silane to $\mathbf{K}$ to yield $\mathbf{N}$ is favorable, even more than coordination to $\mathbf{B}$ to yield $\mathbf{G}$ (Figure 4), perhaps because the stabilization of the manganese unsaturation by the $\alpha-F$ atom in $\mathbf{K}$ is weaker than that

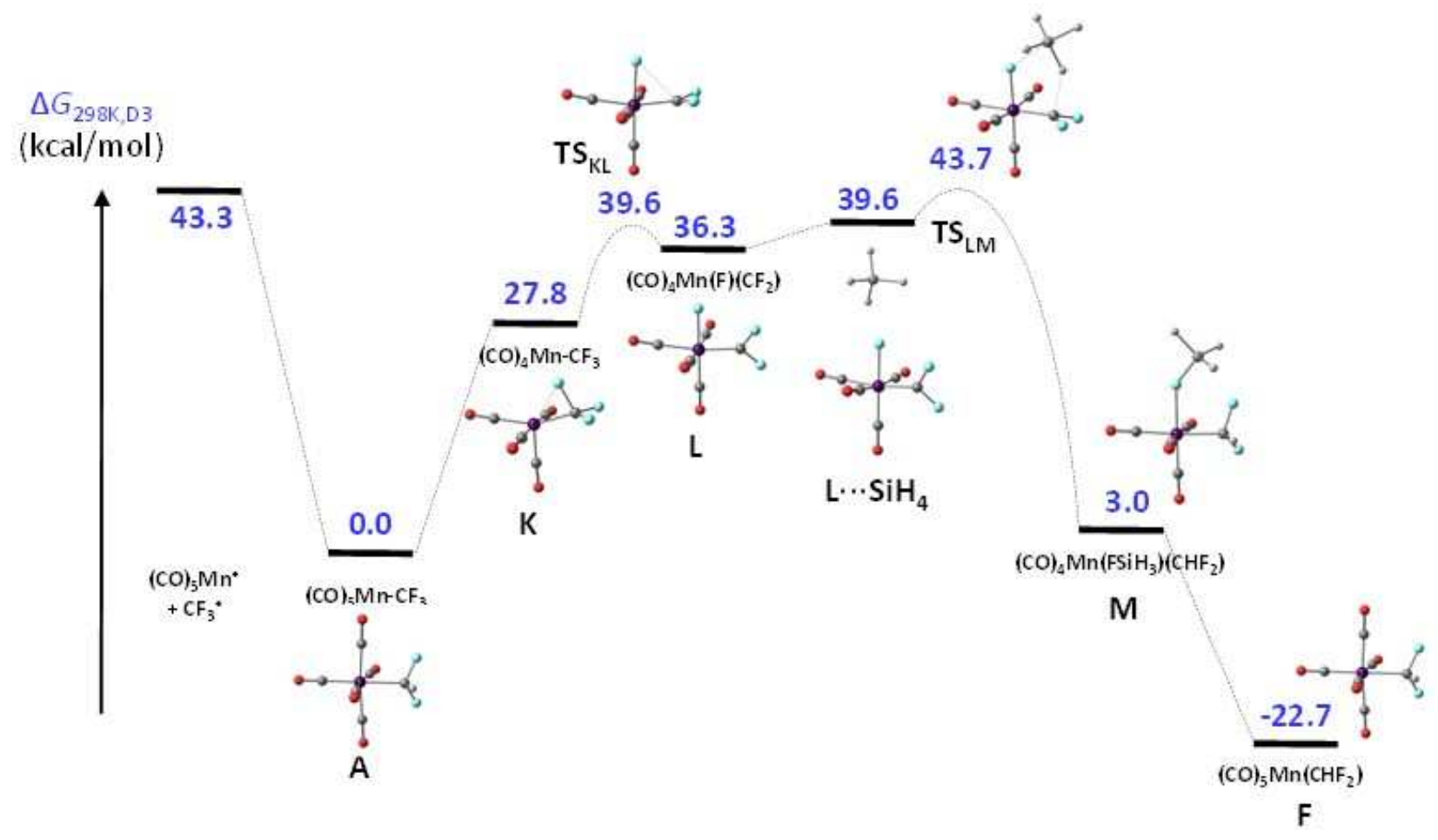

Figure 5. Energy profile (relative $\mathrm{D}_{3}$-corrected $\mathrm{G}_{298}$ values in $\mathrm{kcal} / \mathrm{mol}$ ) and views of the optimized geometries for the $\mathrm{H} / \mathrm{F}$ scrambling pathway triggered by decarbonylation in compound $\mathbf{1}$ (Scheme 3). 


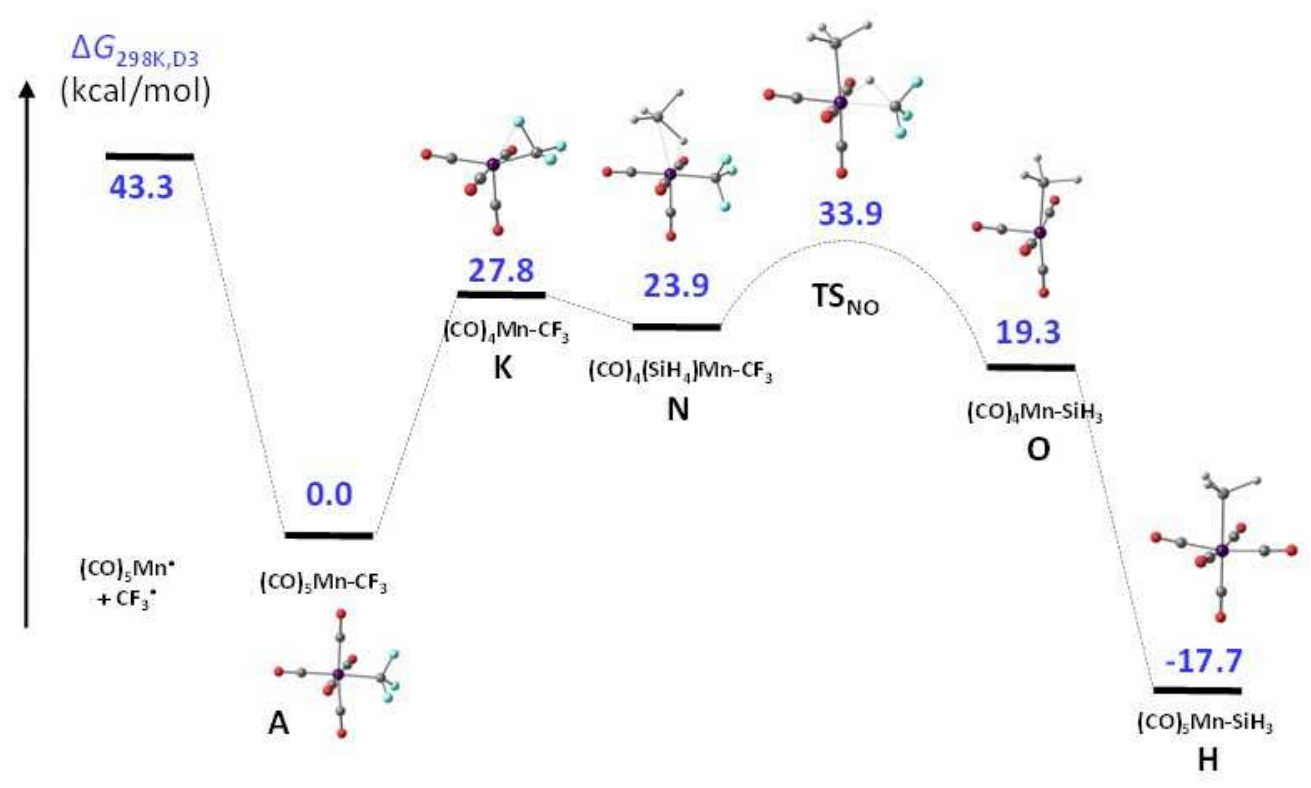

Figure 6. Energy profile (relative $\mathrm{D}_{3}$-corrected $\mathrm{G}_{298}$ values in $\mathrm{kcal} / \mathrm{mol}$ ) and views of the optimized geometries for the $\mathrm{CHF}_{3}$ product release triggered by decarbonylation in compound $\mathbf{1}$ (Scheme 3 ).

by the $\beta-F$ atom in $\mathbf{B}$. The rate-determining transition state $\left(\mathbf{T S}_{\mathrm{NO}}\right)$ of the $\mathrm{H}$ transfer from the silane ligand to the $\mathrm{CF}_{3}$ group is lower than the energy of the bond cleavage products.

(c) Formation of RF-H: homolytic cleavage or silane assisted?

The relatively facile formation of the $\mathrm{R}_{\mathrm{F}}-\mathrm{H}$ by the silaneassisted pathway of Scheme 3 and illustrated in Figure 6, as suggested by the DFT calculations, led us to question whether this may be the operating pathway, rather than the homolytic bond cleavage, for the decomposition of the $\left[\mathrm{Mn}\left(\mathrm{R}_{\mathrm{F}}\right)(\mathrm{CO})_{5}\right]$ compounds $\mathbf{1}, \mathbf{2}$ and 3 in the presence of TTMSS, which was reported and kinetically assessed in our recent contribution. ${ }^{1}$ In order to learn more about this, the activation parameters $\left(\Delta H^{\ddagger}\right.$ and $\left.\Delta S^{\ddagger}\right)$ for the pathway of Figure 6 were derived under the conditions used for the decomposition experiments. The experiments were carried out in the temperature range $85-100{ }^{\circ} \mathrm{C},{ }^{1}$ but since the individual values of $\Delta H^{\ddagger}$ and $\Delta S^{\ddagger}$ are supposed to vary very little in this range, the calculations were carried out only at $100{ }^{\circ} \mathrm{C}$. The major effect on the variation of $\Delta G^{\ddagger}$ is related to the change of $T$ in the $\left(\Delta H^{\ddagger}-T \Delta S^{\ddagger}\right)$ expression. These values are listed in Table 2 (raw data are in SI, Table S.B6), where they are compared with the corresponding values calculated for the homolytic bond cleavage at the same temperature. These can also be compared with the experimentally determined activation parameters shown in Table 1 . These calculations were also extended to the critical structures related to both pathways for the decomposition of 2 and 3, still using $100{ }^{\circ} \mathrm{C}$ as representative temperature.

Two relevant points emerge from this comparison. The first one is that, although the calculated $\Delta G$ value of the homolytic cleavage pathway remains higher than the $\Delta G^{\ddagger}$ of the silane-assisted pathway $\left(\mathbf{T S}_{\mathrm{NO}}\right)$ for all three systems and at both temperatures, the gap between the two $\Delta G$ values is significantly reduced upon raising the temperature, because of the large positive $\Delta S$ of the homolytic bond cleavage process $v s$. the much smaller value of the silane-assisted process. The near-zero activation entropy of the silane-assisted pathway

Table 2. DFT-calculated parameters $\left(\Delta \mathrm{G}\right.$ and $\Delta \mathrm{H}$ values in $\mathrm{kcal} \mathrm{mol}^{-1}$; $\Delta S$ values in $\left.\mathrm{cal} \mathrm{mol}^{-1} \mathrm{~K}^{-1}\right)$ for the generation of $\mathrm{R}_{\mathrm{F}}-\mathrm{H}$ at different temperatures. ${ }^{\mathrm{a}}$

\begin{tabular}{|c|c|c|c|}
\hline Parameter & $\mathrm{R}_{\mathrm{F}}=\mathrm{CF}_{3}(\mathbf{1})$ & $\mathrm{R}_{\mathrm{F}}=\mathrm{CHF}_{2}(\mathbf{2})$ & $\mathrm{R}_{\mathrm{F}}=\mathrm{CH}_{2} \mathrm{CF}_{3}(3)$ \\
\hline \multicolumn{4}{|l|}{ Homolytic cleavage } \\
\hline$\Delta G_{298} / \Delta H_{298} / \Delta S_{298}$ & $43 \cdot 3 / 55.1 / 39.6$ & $37.0 / 48.0 / 37.1$ & $37.9 / 50.5 / 42.5$ \\
\hline$\Delta G_{373} / \Delta H_{373} / \Delta S_{373}$ & $39.9 / 54.8 / 40.1$ & $33.8 / 47.8 / 37.8$ & $34.2 / 50.5 / 43.6$ \\
\hline \multicolumn{4}{|c|}{ Silane-assisted pathway (Figure 6) } \\
\hline$\Delta G^{\ddagger}{ }_{298} / \Delta H^{\ddagger}{ }_{298} / \Delta S_{298}^{\ddagger}$ & $33.8 / 32.9 /-3.4$ & $31.9 / 29 \cdot 5 /-6.1$ & $27.4 / 26.2 /-3.9$ \\
\hline$\Delta G_{373}^{\ddagger} / \Delta H_{373}^{\ddagger} / \Delta S_{373}^{\ddagger}$ & $34.1 / 32.9 /-3.3$ & $31.8 / 29 \cdot 5 /-6.1$ & $27 \cdot 7 / 26.2 /-3.8$ \\
\hline
\end{tabular}

a Difference between $\mathbf{T S}_{\mathrm{NO}}+\mathrm{CO}$ and $\mathbf{A}+\mathrm{SiH}_{4}$. 


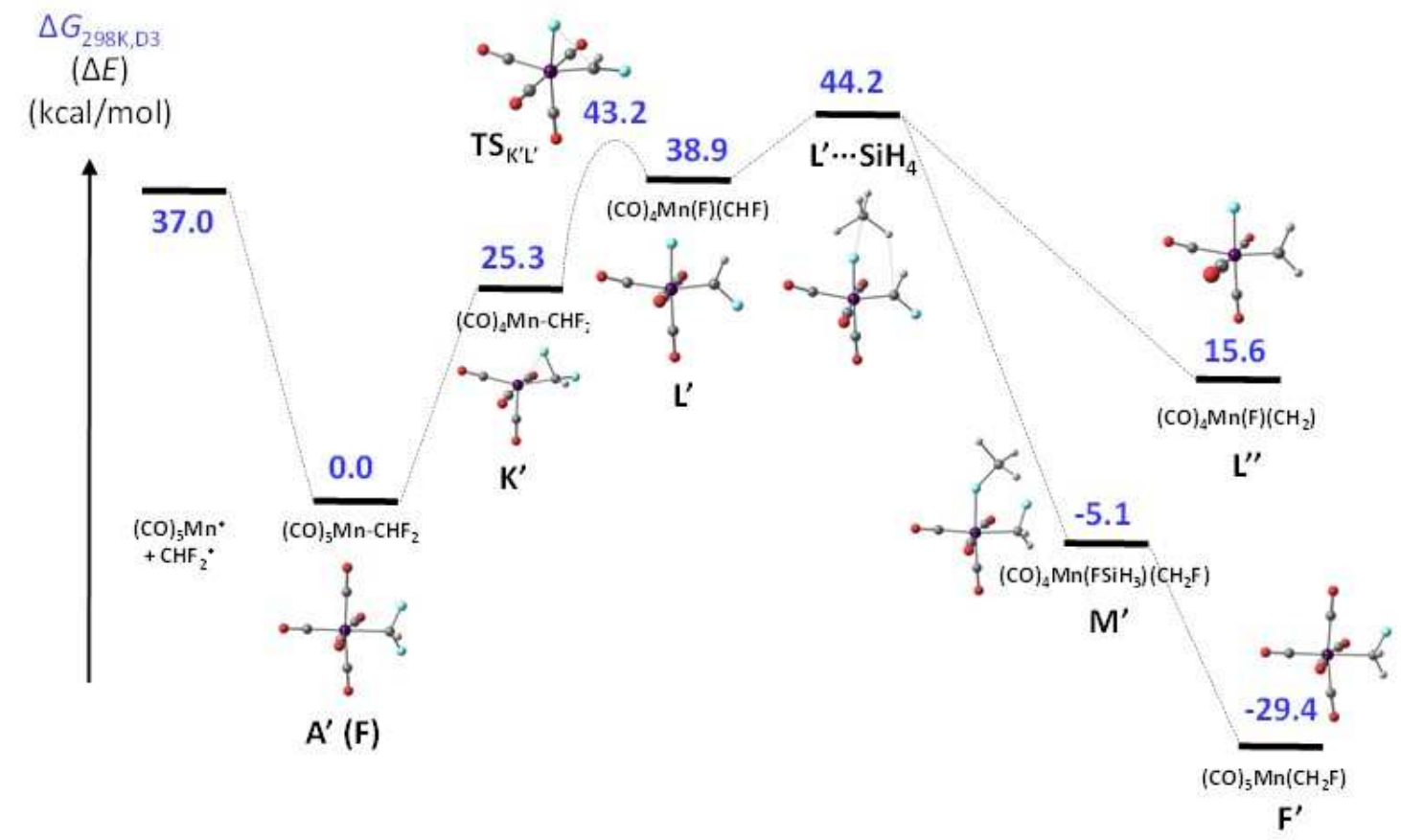

Figure 7. Energy profile (relative $\mathrm{D}_{3}$-corrected $\mathrm{G}_{298}$ values in $\mathrm{kcal} / \mathrm{mol}$ ) and views of the optimized geometries for the $\mathrm{H} / \mathrm{F}$ scrambling pathway triggered by decarbonylation in compound $\mathbf{2}$ (Scheme 4).

results from the balance of the positive $\mathrm{CO}$ dissociation entropy and the negative silane coordination entropy. The second point is that the calculated $\Delta S^{\ddagger}$ of the silane-assisted pathway is in much greater disagreement than that of the homolytic bond breaking process with the experimental $\Delta S^{\ddagger}$ value, which is positive and large (see Table 1$).{ }^{1}$ This observation allows us to conclude that the major, or exclusive, pathway leading to the $\mathrm{R}_{\mathrm{F}}-\mathrm{H}$ evolution must be the homolytic bond cleavage completed by radical trapping, as initially anticipated (Scheme 1). The reason why the calculations wrongly predict a preference for the silane-assisted pathway may be related to the use of $\mathrm{SiH}_{4}$ as a simplified model for the much bulkier TTMSS. While the barrier of the homolytic cleavage does not depend on the silane nature, the energy of the rate-determining TS of the silane-assisted pathway should be raised by the steric encumbrance of the TTMSS molecule. In order to validate this proposition, the $\Delta G^{\ddagger}$ value of this pathway was recalculated for the full A+TTMSS system using the QM/MM approach (see details in the SI), yielding a significantly higher barrier of $42.4 \mathrm{kcal} / \mathrm{mol}$. Although this barrier remains slightly smaller than that of the homolytic cleavage, the uncertainly related to the computational precision is clearly greater. The experimentally measured large activation entropy is the strongest evidence in favor of homolytic cleavage. We can anticipate, however, that use of a less sterically demanding silane as a trapping agent may induce generation of $\mathrm{R}_{\mathrm{F}}-\mathrm{H}$ by the alternative silane-assisted pathway. Therefore, the computational study strongly supports the proposition, made in our recent contribution, ${ }^{1}$ that the thermal decomposition of $\mathbf{1 - 3}$ in the presence of TTMSS oc- curs by Mn- $\mathrm{R}_{\mathrm{F}}$ homolytic cleavage according to Scheme 1. Indeed, this proposition was further suggested by the experimental observation that compound $\mathbf{1}$ is able to initiate the radical polymerization of vinylidene fluoride. ${ }^{1}$

(d) DFT investigation of the H/D exchange pathway for compound 2

From the full investigation of the decomposition of $\mathbf{1}$ described above we have learned that the H/D scrambling pathway proceeds via $\mathrm{CO}$-dissociation and $\alpha$-F elimination. We were interested in probing the importance of this pathway for both compounds 1 and 2, relative to the $\mathrm{Mn}-\mathrm{C}$ homolytic cleavage, because the experimental study shows a very different impact of this secondary reaction in the order $1>2$. Therefore, the H/F exchange pathway according to Scheme 3 for compound $\mathbf{1}$ has also been calculated for compound 2 (Scheme 4) and the resulting energy profile is shown in Figure 7 , once again in comparison with the homolytic $\mathrm{Mn}-\mathrm{CHF}_{2}$ bond cleavage on the left-hand side. For clarity, the labels are the same as in Scheme 3 with an additional prime symbol.

Scheme 4. H/F exchange pathway for compound 2.

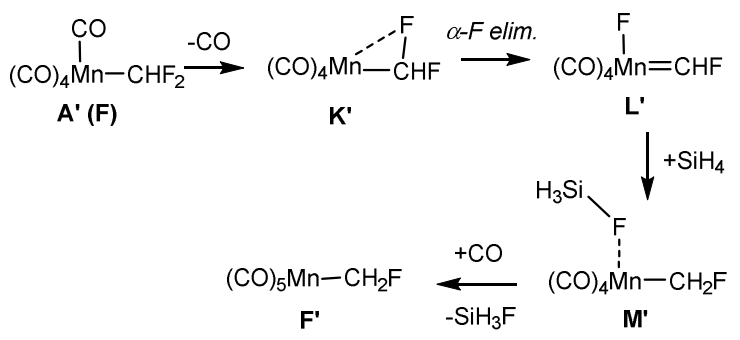


The energy profile for the H/F exchange pathway of compound $\mathbf{2}$ is very similar to that of compound $\mathbf{1}$ (Figure 5 ). The decarbonylation process of A' (compound $\mathbf{2}$ ) to generate $\mathbf{K}^{\prime}$ is a bit less energy demanding than the generation of the corresponding $\mathbf{K}$ from compound $\mathbf{1}$, possibly because of a better stabilization of unsaturation by the $\mathrm{F}$ atom in the less electron withdrawing $\mathrm{CHF}_{2}$ group. On the other hand, the subsequent $\alpha-F$ elimination process has a higher barrier and leads to a less stable alkylidene derivative. Whereas the transition state leading to this intermediate for compound $\mathbf{I}$ $\left(\mathrm{TS}_{\mathrm{KL}}\right)$ is lower than the homolytic bond cleavage products, the reverse is true for the pathway in compound $\mathbf{2}\left(\mathbf{T S}_{\mathbf{K}^{\prime} \mathbf{L}}\right)$. The better stabilization of the system, relative to the starting $\left[\mathrm{Mn}\left(\mathrm{R}_{\mathrm{F}}\right)(\mathrm{CO})_{5}\right]$ by difluorocarbene in $\mathbf{L}$ than by fluorocarbene in $L$ ' may be related to the greater stabilizing effect by $\pi$ backdonation than by $\sigma$ donation. The van der Waals adduct with $\mathrm{SiH}_{4}, \mathbf{L} \cdots \mathrm{SiH}_{4}$, could also be located for system $\mathbf{2}$, but the transition state $\mathbf{T S}_{\mathbf{L}^{\prime} \mathbf{M}}$ could not, in spite of several attempts guided by relaxed scans. Probably, the collapse to the $\mathrm{H} / \mathrm{F}$ scrambled product $\left[\mathrm{Mn}\left(\mathrm{CH}_{2} \mathrm{~F}\right)(\mathrm{CO})_{4}\left(\mathrm{FSiH}_{4}\right)\right]\left(\mathbf{M}^{\prime}\right)$ has a very low barrier with a shallow (low imaginary frequency) transition state, making the optimization of this stationary point particularly problematic. There is in fact a greater thermodynamic drive for $\mathbf{L}^{\prime} \rightarrow \mathbf{M}$ ' than for $\mathbf{L} \rightarrow \mathbf{M}$. On the basis of Hammond's principle, this step is therefore expected to be associated with a lower barrier for $\mathbf{2}$. During one of the several relaxed scans aimed at locating $\mathbf{T S}_{\mathbf{L}^{\prime} \mathbf{M}}$, it was also found that $\mathrm{SiH}_{4}$ can easily exchange its $\mathrm{H}$ atom directly with the $\mathrm{F}$ atom on the alkylidene group. This leads to the alkylidene complex L", which is also shown in Figure 7, and represents another mechanism leading to the same result of $\mathrm{H} / \mathrm{F}$ exchange. We were also unable to locate the transition state for this process. A view of a representative point along the relaxed scan of this new pathway is shown in the SI (Figure S.B5).

It is now appropriate to compare the relative activation barriers for the homolytic bond breaking process and for the $\mathrm{H} / \mathrm{F}$ exchange process under the conditions used for the decomposition experiments. For compound 2, the van der Waals adduct $\mathrm{L}^{\prime} \cdot \mathrm{SSiH}_{4}$ was used as a low estimate of the ratelimiting transition state for the $\mathrm{H} / \mathrm{F}$ exchange process, since the latter could not be optimized. Once again, since the $H$ and $S$ values do not change dramatically with temperature in the $70-100{ }^{\circ} \mathrm{C}$ range and the change in $\Delta G$ is mostly related to the effect of $T$ in the $(\Delta H-T \Delta S)$ expression, the calculations were only carried out at the representative temperature of $100{ }^{\circ} \mathrm{C}$. The results are supplied in Table 3, with the raw energy data in SI, Table S.B9. The barrier height on the $G$ scale does not change very much with temperature, because the $\Delta S$ value is relatively small, resulting from the compensation between the $\mathrm{CO}$ dissociation and $\mathrm{SiH}_{4}$ association.

Table 3. DFT-calculated activation parameters $(\Delta G$ and $\Delta H$ values in $\mathrm{kcal} \mathrm{mol}^{-1}$; $\Delta S$ values in cal $\mathrm{mol}^{-1} \mathrm{~K}^{-1}$ ) for the $H / F$ scrambling at different temperatures for compounds 1 and $2 .^{a}$

$$
\begin{aligned}
& \text { Parameter } \\
& \mathrm{R}_{\mathrm{F}}=\mathrm{CF}_{3}(\mathbf{1}) \\
& \mathrm{R}_{\mathrm{F}}=\mathrm{CHF}_{2}(\mathbf{2}) \\
& \Delta G^{\ddagger}{ }_{298} / \Delta H^{\ddagger}{ }_{298} / \Delta S^{\ddagger}{ }_{298} \\
& \text { 43.7/43.6/-0.3 } \\
& \text { 44.2/45.5/4.6 } \\
& \Delta G^{\ddagger}{ }_{373} / \Delta H^{\ddagger}{ }_{373} / \Delta S^{\ddagger}{ }_{373} \\
& \text { 43.7/43.8/0.0 } \\
& 43 \cdot 8 / 45 \cdot 9 / 5 \cdot 6
\end{aligned}
$$

a Difference between $\mathbf{T S}_{\mathbf{L M}}+\mathrm{CO}$ and $\mathbf{A}+\mathrm{SiH}_{4}$ for compound 1; estimated from the difference between $\mathbf{L}^{\prime} \cdot{ }^{\prime} \cdot \mathrm{SiH}_{4}+\mathrm{CO}$ and $\mathbf{A}^{\prime}+\mathrm{SiH}_{4}$ for compound $\mathbf{2}$.

A comparison of the barriers of the two competitive processes, namely homolytic bond cleavage (Table 2) and H/F exchange (Table 3 ), the balance is much more in favor of homolytic bond cleavage for compound $2(33.8 \mathrm{kcal} / \mathrm{mol} v s .43 .8$ for the competitive $\mathrm{H} / \mathrm{F}$ exchange pathway) than for compound 1 ( $39.9 \mathrm{kcal} / \mathrm{mol} v s .43 .7$ for the alternative pathway). This difference essentially derives from the weaker $\mathrm{Mn}-\mathrm{CHF}_{2}$ bond in 2 relative to the $\mathrm{Mn}-\mathrm{CF}_{3}$ bond in $\mathbf{1}$ (Table 2), whereas the barriers to the H/F exchange process for the two compounds are essentially unchanged (or slightly in favor of $\mathbf{1}$, considering that the value calculated for $\mathbf{2}$ is a low estimate, Table 3). This trend is qualitatively in agreement with the experimentally observed greater impact of the $\mathrm{H} / \mathrm{F}$ exchange process for compound $\mathbf{1}$ than for compound $\mathbf{2}$.

Finally, we consider the impact of the H/F exchange reaction on the kinetic estimation of the Mn- $\mathrm{R}_{\mathrm{F}}$ bond strength by the thermal decomposition study, ${ }^{1}$ particularly in the case of compound $\mathbf{1}$ for which this secondary reaction occurs to a greater extent. An important indicator is the activation entropy, which was experimentally determined as large and positive for all three compounds (Table 1). The computed $\Delta S$ values for the homolytic bond cleavage are also positive, although lower (Table 2), whereas the $\mathrm{H} / \mathrm{F}$ exchange reaction for compounds $\mathbf{1}$ and $\mathbf{2}$ is associated to much lower, nearly zero, activation entropies. The experimentally determined values are affected by large uncertainties and the computed values are certainly affected by many approximations, such as the neglect of solvation effects. However, this comparison suggests that the experimentally determined $\Delta S^{\ddagger}$ values are mostly determined by the homolytic bond cleavage process. A safe conclusion is that the experimentally determined $\Delta H^{\ddagger}$ values are low estimates of the activation enthalpy leading to the $\mathrm{Mn}-\mathrm{R}_{\mathrm{F}}$ bond cleavage. The expected error is obviously greater in the presence of a greater fraction of $\mathrm{H} / \mathrm{F}$ exchange: 3 (no exchange) $<2$ (10\% exchange) $<\mathbf{1}(67 \%$ exchange) Upon consideration of the excellent match between the experimental $(50.6 \pm 0.8 \mathrm{kcal} / \mathrm{mol})$ and computed (50.5 $\mathrm{kcal} / \mathrm{mol}$ ) values for compound 3 , and comparison of the experimental and computed values for compounds 1 and 2 (Table 1), we conclude that the effect of the $\mathrm{H} / \mathrm{F}$ exchange pathway on the estimation of the Mn- $R_{F} B D E$ must be quite small, less than $2 \mathrm{kcal} / \mathrm{mol}$, which is within the experimental error on the determined $\Delta H^{\ddagger}$ value.

As a final note, we advance the hypothesis that at least a few of the unidentified minor by-products (in addition to $\mathrm{R}_{\mathrm{F}} \mathrm{H}$ generated by bond cleavage for $\mathbf{1}, \mathbf{2}$ and $\mathbf{3}$ and to the identified $\mathrm{H} / \mathrm{F}$ exchange products for $\mathbf{1}$ and 2 ) result from additional reactivity pathways of the intermediate carbene complexes (L, L' and L" in Figure 5 and Figure 7). It has been widely appreciated that the decomposition of free perfluoroalkyl anions, used during organic synthesis investigations, leads to products derived from difluorocarbene, ${ }^{39-51}$ e.g. tetrafluoroethylene and its polymer from difluorocarbene. For instance, after decoordination of $\mathrm{CF}_{2}$ from $\mathbf{L}$ or CHF from L' or $\mathrm{CH}_{2}$ from L", a silicon reagent (either $\left(\mathrm{Me}_{3} \mathrm{Si}\right)_{3} \mathrm{SiH}$ or $\left(\mathrm{Me}_{3} \mathrm{Si}\right)_{3} \mathrm{SiF}$ or both) could undergo $\mathrm{C}-\mathrm{H}$ oxidative addition to 
the vacant coordination site in $\left[\mathrm{MnF}(\mathrm{CO})_{4}\right]$, eventually leading to different F-containing silicon products and molecules derived from $\mathrm{R}_{\mathrm{F}}$. Other products may derive from oxidative additions across the Si-Si bond of TTMSS. The $\beta$-F elimination from compound 3 (after decarbonylation) does not take place because $\mathrm{TMS}_{3} \mathrm{SiF}$ could not be detected, even in trace amounts, in that experiment. However, we cannot exclude the possible contribution of $\alpha$-H elimination. Full elucidation of these pathways would require additional experimental and computational work.

\section{Conclusion}

Although pentacarbonylmanganese(I) derivatives with fluorinated alkyl groups have long been considered as thermally robust compounds, our recent investigations ${ }^{1}$ have shown that they are sources of fluorinated alkyl radicals under relatively accessible thermal conditions. The present contribution highlights another phenomenon that accompanies this homolytic bond breaking process, namely the $\alpha-\mathrm{F}$ elimination leading to $\mathrm{H} / \mathrm{F}$ exchange in the presence of the $\mathrm{H}$ atom donor TTMSS. This process is revealed by the formation of $\left(\mathrm{Me}_{3} \mathrm{Si}\right)_{3} \mathrm{SiF}$ and F-poorer fluoroalkanes, as evidence by the ${ }^{1} \mathrm{H}$ and ${ }^{19} \mathrm{~F}$ NMR investigations, and occurs only for compounds $\mathbf{1}$ and 2, which contain $\mathrm{F}$ atoms in the $\alpha$ position, but not for compound 3 where the $F$ atoms are located only on the $\beta-C$ atom. For other previously investigated systems, it was shown that $\alpha$-F elimination is preferred over $\beta$-F elimination when both $\alpha$ and $\beta$ C-F bonds are present. ${ }^{31,32,35,36,38}$ This phenomenon has been documented for late transition metals such as iridium ${ }^{32}$ and particularly nickel, ${ }^{31,} 34-3^{8}$ but is apparently undocumented for the earlier part of the transition series. It is shown here for the first time in organomanganese chemistry.

The DFT study suggests that this process is only possible after creating a vacant coordination site on the Mn center by $\mathrm{CO}$ dissociation, whereas the alternative migratory insertion followed by $\beta$-F elimination is not viable. Furthermore, the impact of this $\mathrm{H} / \mathrm{F}$ exchange pathway decreases in the order $\mathbf{1}>\mathbf{2}$ because the $\mathrm{Mn}-\mathrm{C}$ bond weakens in the same direction, whereas the barrier to the $\mathrm{H} / \mathrm{F}$ exchange remains approximately unchanged. The analysis of the barriers of these two competing processes at $100{ }^{\circ} \mathrm{C}$ has validated the proposition ${ }^{1}$ that the determined $\Delta H^{\ddagger}$ values for the thermal decomposition are good estimates of the Mn- $\mathrm{R}_{\mathrm{F}} \mathrm{BDE}$. The generation of other minor by-products, as revealed by the ${ }^{19} \mathrm{~F}$ NMR spectra, indicates the presence of yet additional reaction pathways undertaken by one or more of the thermally generated intermediates from the starting $\left[\mathrm{Mn}\left(\mathrm{R}_{\mathrm{F}}\right)(\mathrm{CO})_{5}\right]$ complexes. These pathways are, however, much less important than the H/F exchange pathway analyzed in the present contribution.

\section{Experimental Section}

General. All operations were carried out under argon in a NMR tube inside the NMR spectrometer. Compounds tris(trimethylsilyl)silane (TTMSS, 97\%, Sigma-Aldrich), hexafluorobenzene (99\%, Aldrich), benzene- $\mathrm{d}_{6}$ (99.5\% D, Euriso-top) were used as received. Compounds 1, 2, 3 were synthesized as recently described. ${ }^{1}$ The Nuclear Magnetic Resonance (NMR) spectra were obtained with a Bruker
Avance III $400 \mathrm{MHz}$ spectrometer. The instrumental parameters for recording spectra were as follows: ${ }^{19} \mathrm{~F}$ NMR: flip angle $30^{\circ}$, acquisition time $2 \mathrm{~s}$, pulse delay $2 \mathrm{~s}$, number of scans 1 , and a pulse width of $3.76 \mu$ s. The probe has a lower background ${ }^{19} \mathrm{~F}$ signals compared to standard dual-channel probes.

Investigation of the Homolytic Mn- $\mathrm{R}_{\mathrm{F}}$ Bond Cleavage. All experiments were carried out using the same procedure. As a representative example, $\left[\mathrm{Mn}\left(\mathrm{CF}_{3}\right)(\mathrm{CO})_{5}\right](159.3 \mathrm{mg}$, o.6o $\mathrm{mmol}$ ) was dissolved in $5.0 \mathrm{~mL}$ of $\mathrm{C}_{6} \mathrm{D}_{6}$ together with 8 drops of $\mathrm{C}_{6} \mathrm{~F}_{6}$ as internal standard. Aliquots of this solution $(0.5 \mathrm{~mL})$ were transferred into NMR tubes, then the desired amount of TTMSS was added and the thermal decomposition was monitored at the desired temperatures by ${ }^{19} \mathrm{~F}$ NMR spectroscopy.

Computational Details. The computational work was carried out using the Gaussianog suite of programs..$^{22}$ Gasphase geometry optimizations were performed without any symmetry constraint using the BPW91* functional, which is a reparametrized version of $\mathrm{B}_{3} \mathrm{PW}_{91}$ with the same parameters previously optimized for $\mathrm{B}_{3} \mathrm{LYP},{ }^{53}$ and the $6-31 \mathrm{G}(\mathrm{d}, \mathrm{p})$ basis functions for all light atoms ( $\mathrm{H}, \mathrm{C}, \mathrm{F}, \mathrm{O}, \mathrm{S})$, whereas the $\mathrm{Mn}$, atom was treated with the SDD basis set augmented by an $\mathrm{f}$ polarization function $(\alpha=2.195) .{ }^{54}$ The unrestricted formulation was used for open-shell molecules, yielding only minor spin contamination $\left(<\mathrm{S}^{2}>\right.$ at convergence was very close to the expected value of 0.75 for doublet states, the maximum deviation being 0.757 for $\left.\left[\mathrm{Mn}(\mathrm{CO})_{5}\right]^{\circ}\right)$. All final geometries were characterized as local minima by verifying that all second derivatives of the energy were positive. Thermochemical corrections were obtained at $298.15 \mathrm{~K}$ and at $373 \mathrm{~K}$ on the basis of frequency calculations, using the standard approximations (ideal gas, rigid rotor and harmonic oscillator). Corrections for dispersion were carried out at the fixed BPW91* optimized geometries using Grimme's $\mathrm{D}_{3}$ empirical method (BPW91*-D3), using SR6 and S8 parameters identical to those optimized for $\mathrm{B}_{3} \mathrm{PW} 91 .{ }^{55} \mathrm{~A}$ further correction of 1.95 $\mathrm{Kcal} / \mathrm{mol}$ was applied to bring the $\mathrm{G}$ values from the gas phase $(1 \mathrm{~atm})$ to the solution $(1 \mathrm{~mol} / \mathrm{L})$ standard state. ${ }^{56}$ Since the reactions were carried out in the apolar $\mathrm{C}_{6} \mathrm{D}_{6}$ solvent, no solvation correction was applied. For the QM/MM calculations, the MM part was treated with the UFF57 methodology. In all systems, the TTMSS fragment was handled with the $\mathrm{Si}_{3} \mathrm{SiH}$ at the QM level and the nine $\mathrm{CH}_{3}$ groups at the MM level.

\section{ASSOCIATED CONTENT}

NMR spectra of the thermally decomposed $\left[\mathrm{Mn}\left(\mathrm{R}_{\mathrm{F}}\right)(\mathrm{CO})_{5}\right]$ $\mathrm{C}_{6} \mathrm{D}_{6}$ solutions $\left(\mathrm{R}_{\mathrm{F}}=\mathrm{CF}_{3}, \mathrm{CF}_{2} \mathrm{H}, \mathrm{CH}_{2} \mathrm{CF}_{3}\right)$. Details of the DFToptimized structures.

\section{AUTHOR INFORMATION}

\section{Corresponding Author}

* Rinaldo Poli, Laboratoire de Chimie de Coordination, 205 Route de Narbonne, 31077 Toulouse, France. Fax: +33561553003. E-mail: rinaldo.poli@lcc-toulouse.fr. *Bruno Améduri, Ingénierie et Architectures Macromoléculaires, Institut Charles Gerhardt, UMR 5253 CNRS, UM, ENSCM, Place Eugène Bataillon, 34095 Montpellier Cedex 5, 
France. Fax: +33-467147220. E-mail: bruno.ameduri@en$\underline{\text { scm.fr. }}$

\section{Author Contributions}

The manuscript was written through contributions of all authors. All authors have given approval to the final version of the manuscript.

\section{Funding Sources}

Agence Nationale de la Recherche (French National Agency), grant No. ANR-14-CE07-0012 (FLUPOL).

\section{Notes}

The authors declare no conflict of interest

\section{ACKNOWLEDGMENT}

This work was supported by the Agence Nationale de la Recherche (ANR) through the project FLUPOL (grant No. ANR14-CE07-0012). We also gratefully acknowledge additional financial support from the Centre National de la Recherche Scientifique (CNRS). We thank Mr. Cédric Totée and Pr. Gilles Silly for their help in NMR spectroscopy. This work was granted access to the HPC resources of IDRIS under the allocation 2016-086343 made by GENCI (Grand Équipement National de Calcul Intensif) and to the resources of the CICT (Centre Interuniversitaire de Calcul de Toulouse, project CALMIP).

\section{ABBREVIATIONS}

TTMSS, tris(trimethylsilyl)silane.

\section{REFERENCES}

1. Morales-Cerrada, R.; Fliedel, C.; Daran, J.-C.; Gayet, F.; Ladmiral, V.; Améduri, B.; Poli, R., Fluoroalkyl radical generation by homolytic bond dissociation in pentacarbonylmanganese derivatives. Chem. Eur. J. 2018, https://doi.org/10.1002/chem.201804007.

2. Dolbier, W. R., Structure, reactivity, and chemistry of fluoroalkyl radicals. Chem. Rev. 1996, 96, 1557-1584.

3. Améduri, B.; Boutevin, B., Well-Architectured Fluoropolymers: Synthesis, Properties and Applications. Elsevier Science: Amsterdam, 2004.

4. Améduri, B., Controlled Radical (Co)polymerization of Fluoromonomers. Macromolecules 2010, 43, 10163-10184.

5. Banerjee, S.; Ladmiral, V.; Debuigne, A.; Detrembleur, C.; Poli, R.; Améduri, B., Organometallic Mediated Radical Polymerization of Vinylidene Fluoride. Angew. Chem. Int. Ed. 2018, 57, 2934-2937.

6. Waltz, W. L.; Hackelberg, O.; Dorfman, L. M.; Wojcicki, A., Pulse-radiolysis studies of decacarbonyldimanganese(o) and halopentacarbonylmanganese(I) - pentacarbonylmanganese(o) radical. J. Am. Chem. Soc. 1978, 100, 7259-7264.

7. Ishikawa, M.; Nakamura, A.; Kumada, M., Stable silyl radicals. Novel route to branched-chain methylpolysilanes. J. Organometal. Chem. 1973, 59, C11-C12.

8. Nicholson, B. K.; Simpson, J., Polysilane derivatives of the transition metals. I. Synthesis of tris(trimethylsilyl)silyl manganese pentacarbonyl and related compounds. J. Organometal. Chem. 1971, 32, C29-C30.

9. Nicholson, B. K.; Simpson, J.; Robinson, W. T., Polysilane derivatives of the transition metals. II. Crystal and molecular structure [tris(trimethylsilyl)silyl]pentacarbonylmanganese. Organometal. Chem. 1973, 47, 403-412.
10. Nicholson, B. K.; Simpson, J., Polysilane derivatives of the transition metals. III. Preparations and spectra of manganese and iron derivatives. J. Organometal. Chem. 1974, 72, 211-20.

11. Poli, R.; Rahaman, S. M. W.; Ladmiral, V.; Améduri, B., Effect of $\alpha$ - and $\beta-\mathrm{H} / \mathrm{F}$ substitution on the homolytic bond strength in dormant species of controlled radical polymerization: OMRP vs. ITP and RAFT. J. Organomet. Chem. 2018, 864, 12-18

12. Folga, E.; Ziegler, T., A density functional study on the strength of the metal bonds in $\mathrm{Co}_{2}(\mathrm{CO})_{8}$ and $\mathrm{Mn}_{2}(\mathrm{CO})_{10}$ and the metal-hydrogen and metal-carbon bonds in R-Mn(CO $)_{5}$ and R$\mathrm{Co}(\mathrm{CO})_{4}$. J. Am. Chem. Soc. 1993, 115, 5169-5176.

13. Connor, J. A.; Zafaranimoattar, M. T.; Bickerton, J.; Elsaied, N. I.; Suradi, S.; Carson, R.; Altakhin, G.; Skinner, H. A., Eenthalpy of formaton of acylpentacarbonylmanganese, alkylpentacarbonylmanganese, and hydridopentacarbonylmanganese compexes - the enthalpy conributions of manganese hydrogen and manganese carbon bonds in these molecules - thermochemical aspects of models in Fischer-Tropsch reactions. Organometallics 1982, 1, 1166-1174.

14. Martinho Simões, J. A.; Beauchamp, J. L., Transition metal-hydrogen and metal-carbon bond strenghts: the keys to catalysis. Chem. Rev. 1990, 90, 629-688.

15. Fujita, T.; Fuchibe, K.; Ichikawa, J., Transition MetalMediated and -Catalyzed C-F Bond Activation via Fluorine Elimination. Angew. Chem. Int. Ed. 2018, 57, 2-15.

16. Frankiss, S. G., Nuclear magnetic resonance (N.M.R.) spectra of some substituted methanes. J. Phys. Chem. 1963, 67, 752-755.

17. Sartori, P.; Habel, W., Electrofluorination of chloromethylsulfochloride. J. Fluorine Chem. 1980, 16, 265-276.

18. Sartori, P.; Habel, W., Electrochemical fluoration of alpha-chloroethylsulfochloride. J. Fluorine Chem. 1981, 18, 131-141.

19. Buerger, H.; Kilian, W.; Burczyk, K., Preparation, properties, NMR spectra, vibrational spectra, and normal coordinate analysis of tris(trimethylsilyl)halosilanes. J. Organometal. Chem. 1970, 21, 291-301.

20. Marsmann, H. C.; Raml, W.; Hengge, E., Silicon-29 nuclear resonance measurements on polysilanes. 2. Isotetrasilanes. Z. Naturforsch., B Anorg. Chem., Org. Chem. 1980, 35B, 1541-7.

21. Ahrens, M.; Scholz, G.; Braun, T.; Kemnitz, E., Catalytic Hydrodefluorination of Fluoromethanes at Room Temperature by Silylium-ion-like Surface Species. Angew. Chem. Int. Ed. 2013, 52, 5328-5332.

22. Pellerite, M. J., Unusual reaction chemistry in thermal decomposition of alkali-metal 2-alkoxy-2,3,3,3tetrafluoropropionate salts. J. Fluorine Chem. 1990, 49, 43-66.

23. Elleman, D. D.; Brown, L. C.; Williams, D., The nuclear magnetic resonance spectra of fluorocarbons. I. Halogenated ethanes. J. Mol. Spectrosc. 1961, 7, 307-21.

24. Hu, J.; Han, X.; Yuan, Y.; Shi, Z., Stereoselective Synthesis of $\mathrm{Z}$ Fluoroalkenes through Copper-Catalyzed Hydrodefluorination of gem-Difluoroalkenes with Water. Angew. Chem. Int. Ed. 2017, 56, 13342-13346.

25. Kojima, R.; Kubota, K.; Ito, H., Stereodivergent hydrodefluorination of gem-difluoroalkenes: selective synthesis of (Z)- and (E)-monofluoroalkenes. Chem. Commun. 2017, 53, 10688-10691.

26. Zhang, J.; Dai, W.; Liu, Q.; Cao, S., Cu-Catalyzed Stereoselective Borylation of gem-Difluoroalkenes with B(2)pin(2). Org. Lett. 2017, 19, 3283-3286.

27. Kikushima, K.; Sakaguchi, H.; Saijo, H.; Ohashi, M.; Ogoshi, S., Copper-mediated One-pot Synthesis of Trifluorostyrene Derivatives from Tetrafluoroethylene and Arylboronate. Chem. Lett. 2015, 44, 1019-1021. 
28. Sakaguchi, H.; Ohashi, M.; Ogoshi, S., Fluorinated Vinylsilanes from the Copper-Catalyzed Defluorosilylation of Fluoroalkene Feedstocks. Angew. Chem. Int. Ed. 2018, 57, 328-332. 29. Calderazzo, F.; Cotton, F. A., Carbon Monoxide Insertion Reactions. I. The Carbonylation of Methyl Manganese Pentacarbonyl and Decarbonylation of Acetyl Manganese Pentacarbonyl. Inorg. Chem. 1962, 1, 30-36.

30. Calderazzo, F.; Cotton, F. A., CO insertion reactions. II. Reactions of acetylmanganese pentacarbonyl and methylmanganese pentacarbonyl with triphenylphosphine. Chim. Ind. (Milan) 1964, 46, 1165-9.

31. Burch, R. R.; Calabrese, J. C.; Ittel, S. D., Fluoroorganometallic chemistry - carbon fluorine bond activation in perfluorometallacyclopentane complexes. Organometallics 1988, $7,1642-1648$.

32. Bourgeois, C. J.; Hughes, R. P.; Yuan, J.; DiPasquale, A. G.; Rheingold, A. L., alpha- and beta-Fluorine elimination reactions induced by reduction of iridium-fluoroalkyl complexes. Selective formation of fluoroalkylidene and hydrofluoroalkene ligands. Organometallics 2006, 25, 2908-2910.

33. Hughes, R. P., Conversion of Carbon-Fluorine Bonds alpha to Transition Metal Centers to Carbon-Hydrogen, CarbonCarbon, and Carbon-Heteroatom Bonds. Eur. J. Inorg. Chem. 2009, 4591-4606.

34. Takachi, M.; Kita, Y.; Tobisu, M.; Fukumoto, Y.; Chatani, N., Nickel-Catalyzed Cyclization of Difluoro-Substituted 1,6Enynes with Organozinc Reagents through the Stereoselective Activation of C-F Bonds: Synthesis of Bicyclo 3.2.0 heptene Derivatives. Angew. Chem. Int. Ed. 2010, 49, 8717-8720.

35. Giffin, K. A.; Harrison, D. J.; Korobkov, I.; Baker, R. T., Activation of $\mathrm{C}-\mathrm{F}$ and $\mathrm{Ni}-\mathrm{C}$ Bonds of $\mathrm{P}, \mathrm{S}$-Ligated Nickel Perfluorometallacycles. Organometallics 2013, 32, 7424-7430.

36. Andrella, N. O.; Sicard, A. J.; Gorelsky, S. I.; Korobkov, I.; Baker, R. T., A T-shaped Ni kappa(2)-( $\left.\mathrm{CF}_{2}\right)(4)-\mathrm{NHC}$ complex: unusual $\mathrm{C}-\mathrm{sp} 3-\mathrm{F}$ and $\mathrm{M}-\mathrm{C}-\mathrm{F}$ bond functionalization reactions. Chemical Science 2015, 6, 6392-6397.

37. Fujita, T.; Watabe, Y.; Ichitsuka, T.; Ichikawa, J., NiCatalyzed Synthesis of Fluoroarenes via $2+2+2$ Cycloaddition Involving -Fluorine Elimination. Chem. Eur. J. 2015, 21, 1322513228.

38. Ohashi, M.; Ueda, Y.; Ogoshi, S., Nickel(o)-Mediated Transformation of Tetrafluoroethylene and Vinylarenes into Fluorinated Cyclobutyl Compounds. Angew. Chem. Int. Ed. 2017, 56, 2435-2439.

39. Haszeldine, R. N., Perfluoroalkyl Grignard and Grignard-type reagents. IV. Trifluoromethylmagnesium iodide. J. Chem. Soc. 1954, 1273-9.

40. Pierce, O. R.; McBee, E. T.; Judd, G. F., Preparation and reactions of perfluoroalkyllithiums. J. Am. Chem. Soc. 1954, 76, 474-8.

41. Shono, T.; Ishifune, M.; Okada, T.; Kashimura, S., Electroorganic chemistry. 130. A novel trifluoromethylation of aldehydes and ketones promoted by an electrogenerated base. J. Org. Chem. 1991, 56, 2-4.

42. Russell, J.; Roques, N., Effective nucleophilic trifluoromethylation with fluoroform and common base. Tetrahedron 1998, 54, 13771-13782.

43. Folleas, B.; Marek, I.; Normant, J. F.; Saint-Jalmes, L., Fluoroform: An efficient precursor for the trifluoromethylation of aldehydes. Tetrahedron Lett. 1998, 39, 2973-2976.

44. Folleas, B.; Marek, I.; Normant, J. F.; Saint-Jalmes, L., Fluoroform: an efficient precursor for the trifluoromethylation of aldehydes. Tetrahedron 2000, 56, 275-283.

45. Large, S.; Roques, N.; Langlois, B. R., Nucleophilic trifluoromethylation of carbonyl compounds and disulfides with trifluoromethane and silicon-containing bases. J. Org. Chem. 200o, $65,8848-8856$.

46. Langlois, B. R.; Billard, T., Some recent results in nucleophilic trifluoromethylation and introduction of fluorinated moieties. Synthesis-Stuttgart 2003, 185-194.

47. Zanardi, A.; Novikov, M. A.; Martin, E.; Benet-Buchholz, J.; Grushin, V. V., Direct Cupration of Fluoroform. J. Am. Chem. Soc. 2011, 133, 20901-20913.

48. Kawai, H.; Yuan, Z.; Tokunaga, E.; Shibata, N., A sterically demanding organo-superbase avoids decomposition of a naked trifluoromethyl carbanion directly generated from fluoroform. Org. Biomol. Chem. 2013, 11, 1446-1450.

49. Zhang, Y.; Fujiu, M.; Serizawa, H.; Mikami, K., Organocatalysis approach to trifluoromethylation with fluoroform. J. Fluorine Chem. 2013, 156, 367-371.

50. Prakash, G. K. S.; Wang, F.; Zhang, Z.; Haiges, R.; Rahm, M.; Christe, K. O.; Mathew, T.; Olah, G. A., Long-Lived Trifluoromethanide Anion: A Key Intermediate in Nucleophilic Trifluoromethylations. Angew. Chem. Int. Ed. 2014, 53, 11575-11578.

51. Ni, C. F.; Hu, J. B., The unique fluorine effects in organic reactions: recent facts and insights into fluoroalkylations. Chem. Soc. Rev. 2016, 45, 5441-5454.

52. Frisch, M. J.; Trucks, G. W.; Schlegel, H. B.; Scuseria, G. E.; Robb, M. A.; Cheeseman, J. R.; Scalmani, G.; Barone, V.; Mennucci, B.; Petersson, G. A.; Nakatsuji, H.; Caricato, M.; Li, X.; Hratchian, H. P.; Izmaylov, A. F.; Bloino, J.; Zheng, G.; Sonnenberg, J. L.; Hada, M.; Ehara, M.; Toyota, K.; Fukuda, R.; Hasegawa, J.; Ishida, M.; Nakajima, T.; Honda, Y.; Kitao, O.; Nakai, H.; Vreven, T.; Montgomery, J., J. A.; Peralta, J. E.; Ogliaro, F.; Bearpark, M.; Heyd, J. J.; Brothers, E.; Kudin, K. N.; Staroverov, V. N.; Kobayashi, R.; Normand, J.; Raghavachari, K.; Rendell, A.; Burant, J. C.; Iyengar, S. S.; Tomasi, J.; Cossi, M.; Rega, N.; Millam, N. J.; Klene, M.; Knox, J. E.; Cross, J. B.; Bakken, V.; Adamo, C.; Jaramillo, J.; Gomperts, R.; Stratmann, R. E.; Yazyev, O.; Austin, A. J.; Cammi, R.; Pomelli, C.; Ochterski, J. W.; Martin, R. L.; Morokuma, K.; Zakrzewski, V. G.; Voth, G. A.; Salvador, P.; Dannenberg, J. J.; Dapprich, S.; Daniels, A. D.; Farkas, Ö.; Foresman, J. B.; Ortiz, J. V.; Cioslowski, J.; Fox, D. J., Gaussian o9, Revision D.o1. Gaussian, Inc.: Wallingford CT, 2009.

53. Reiher, M., Theoretical study of the Fe(phen)(2)(NCS)(2) spin-crossover complex with reparametrized density functionals. Inorg. Chem. 2002, 41, 69286935 .

54. Ehlers, A. W.; Böhme, M.; Dapprich, S.; Gobbi, A.; Hoellwarth, A.; Jonas, V.; Koehler, K. F.; Stegmann, R.; Veldkamp, A.; Frenking, G., A set of $\mathrm{f}$-polarization functions for pseudopotential basis sets of the transition metals $\mathrm{Sc}-\mathrm{Cu}, \mathrm{Y}-\mathrm{Ag}$ and La-Au. Chem. Phys. Lett. 1993, 208, 111-114.

55. Grimme, S.; Antony, J.; Ehrlich, S.; Krieg, H., A consistent and accurate $\mathrm{ab}$ initio parametrization of density functional dispersion correction (DFT-D) for the 94 elements HPu. J. Chem. Phys. 2010, 132, 154104.

56. Bryantsev, V. S.; Diallo, M. S.; Goddard, W. A., III, Calculation of solvation free energies of charged solutes using mixed cluster/continuum models. J. Phys. Chem. B 2008, 112, 9709-9719.

57. Rappé, A. K.; Casewit, C. J.; Colwell, K. S.; Goddard III, W. A.; Skiff, W. M., UFF, a Full Periodic-Table Force-Field for Molecular Mechanics and Molecular-Dynamics Simulations. J. Am. Chem. Soc. 1992, 114, 10024-10035. 


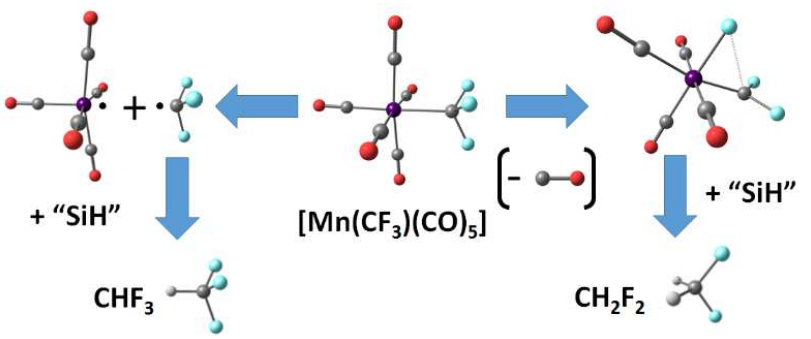

